\title{
Nucleophilic Aromatic Substitution on Pentafluorophenyl- substituted Dipyrranes and Tetrapyrroles as a Route to Multifunctionalized Chromophores for a Potential Application in Photodynamic Therapy
}

\author{
Claudia S. Gutsche, ${ }^{[a, b, c]}$ Marlene Ortwerth,,${ }^{[a, b, c]}$ Susanna Gräfe, ${ }^{[c]}$ Keith J. Flanagan, ${ }^{[d]}$ Mathias O. \\ Senge ${ }^{[\mathrm{d}]}$ Hans-Ulrich Reissig, ${ }^{[\mathrm{b}]}$ Nora Kulak, ${ }^{[\mathrm{a}]}$ Arno Wiehe ${ }^{*[\mathrm{~b}, \mathrm{c}]}$
}

\begin{abstract}
The application of porphyrinoids in biomedical fields like photodynamic therapy (PDT) requires the introduction of functional groups to adjust their solubility in the biological environment and to allow a coupling to other active moieties or carrier systems. A valuable motif in this regard is the pentafluorophenyl (PFP)substituent, as the PFP-group easily undergoes a regiospecific nucleophilic replacement $\left(S_{N} A r\right)$ of the para-fluorine atom by a number of nucleophiles. Here, it is shown that - alternatively to an amino-substitution on the final porphyrinoid or BODIPY - the precursor 5-(PFP)-dipyrrane can be modified with amines (or alcohols). These dipyrranes were transformed into amino-substituted BODIPYs. Condensation of these dipyrranes with aldehydes gives access to trans- $A_{2} B_{2}$-porphyrins and $-A_{2} B$-corroles. Using pentafluorobenzaldehyde another para-fluorine atom can be introduced enabling the synthesis of multifunctionalized tetrapyrroles. Furthermore, alkoxy- and amino-substituted dipyrranes were applied to the synthesis of $A_{3} B_{3}$-hexaphyrins. With this approach polar porphyrins can be prepared, which exhibit in vitro PDT activity against several tumor cell lines.
\end{abstract}

[a] Prof. Dr Nora Kulak

Institut für Chemie und Biochemie, Freie Universität Berlin

Fabeckstrasse 34/36, 14195 Berlin, Germany

E-Mail: nora.kulak@fu-berlin.de

Homepage: http://www.bcp.fu-berlin.de/en/chemie/chemiekulak

[b] Prof. Dr. Hans-Ulrich Reissig

Institut für Chemie und Biochemie, Freie Universität Berlin

Takustr. 3, 14195 Berlin, Germany

E-mail: hans.reissig@chemie.fu-berlin.de

Homepage: http://www.bcp.fu-berlin.de/en/chemie/reissig

[c] Dr. Arno Wiehe

biolitec research $\mathrm{GmbH}$

Otto-Schott-Str. 15, 07745 Jena, Germany

E-mail: arno.wiehe@biolitec.de

Homepage: http://www.biolitec.de

[d] Prof. Dr Mathias O. Senge

School of Chemistry, SFI Tetrapyrrole Laboratory, Trinity Biomedical

Sciences Institute, 152-160 Pearse Street, Trinity College Dublin, the

University of Dublin

Dublin 2, Ireland

E-mail: sengem@tcd.ie

Homepage: http://chemistry.tcd.ie/staff/people/mos/Home.html

Supporting Information for this article is given via a link at the end of the document.

\section{Introduction}

Tetrapyrroles play an important role in various biological systems and in industrial applications. ${ }^{[1]}$ In contrast to the naturally occurring $\beta$-substituted systems (e.g., heme and chlorophyll), synthetic tetrapyrroles are often substituted at the meso-position. ${ }^{[2]}$ Depending on the substituents and the central metal ion they are applied in diverse fields such as catalysis, ${ }^{[3]}$ solar technology, ${ }^{[1, \mathrm{a}, \mathrm{b}, 4]}$ material sciences, ${ }^{[5]}$ and (photo)medicine. ${ }^{[3,6]}$ For all of these applications compounds with a specific substitution pattern are desirable. For a use in, e.g., photodynamic therapy (PDT), amphiphilic compounds combining hydrophilic and hydrophobic substituents are necessary to ensure membrane affinity. ${ }^{[7]}$ Established procedures for the synthesis of porphyrins and corroles are available. However, these condensation reactions employing smaller building blocks (aldehydes, pyrroles, dipyrranes) to construct the macrocycle are not particularly high-yielding. Conversely, there is a continuous interest in methods that either allow an easy post-functionalization of an existing macrocycle or that use precursors which enable different functional groups to be introduced. ${ }^{[8]}$ An approach that has proven to be particularly useful for a post-functionalization of porphyrinoids is the pentafluorophenyl (PFP) substitution. ${ }^{[9]}$ The PFP group readily undergoes a regiospecific nucleophilic replacement $\left(S_{N} A r\right)$ of the para-fluorine atom ${ }^{[9]}$ by a diverse set of nucleophiles and is suitable for a post-modification of porphyrin ${ }^{[9 a-c, 10]}$ or corrole macrocycles. ${ }^{[11]}$ Various nucleophilic substitution reactions at the para-position of meso-PFP substituents of porphyrins or corroles with alcohols, ${ }^{[9 a, c, 10 b, 12]}$ amines, ${ }^{[9 a, c, 10 b, 11,13]}$ and thiols ${ }^{[9 a, c, 10 b, 13 a, b, 14]}$ are known. However, apart from this post-functionalization of a PFP-substituted macrocycle a functionalization of the precursors (aldehydes, dipyrranes) is especially attractive as this allows the specific synthesis of, e.g., trans- $\mathrm{A}_{2} \mathrm{~B}_{2}$-porphyrins or trans- $\mathrm{A}_{2} \mathrm{~B}-$ corroles, carrying two different substituents in a defined arrangement. In the literature some examples for the nucleophilic substitution of pentafluorobenzaldehyde are given $^{[9 f, 15]}$ and recently, the first nucleophilic substitution with alcohols on PFP-dipyrrane and their subsequent use in the synthesis of porphyrins and corroles has been described. ${ }^{[16]}$ With the intention to further expand this approach here the nucleophilic substitution of amines on PFP-dipyrrane and the suitability of such functionalized dipyrranes for porphyrinoid synthesis is investigated. Thereby, the focus lies on the synthesis of porphyrinoids carrying different functional groups for biomedical applications like PDT, i.e. polar groups (hydroxyl, 
amino) which increase the solubility of the highly lipophilic macrocycle in the biological environment and groups that enable a coupling to other active moieties or carrier systems (azido, alkynyl, alkenyl). ${ }^{[6]}$

\section{Results and Discussion}

\section{Synthesis}

Dipyrromethanes or dipyrranes are well-known precursors for porphyrinoid synthesis, ${ }^{[17]}$ employed, e.g., for preparing porphyrins, expanded porphyrins, corroles or reduced porphyrin systems like chlorins, calixphyrins or calixpyrroles (porphyrinogens). ${ }^{[\mathrm{a}, 17 \mathrm{f}, \mathrm{g}, 18]}$ Meso- or 5-substituted dipyrranes are simply accessible by the condensation of an excess of pyrrole and the desired aldehyde though other efficient synthetic protocols have also been reported. ${ }^{[8 a, 17 a, b, e, g, 19]}$ The stability of meso-substituted dipyrranes depends on their substitution pattern with electron-withdrawing substituents stabilizing the dipyrrane toward "scrambling" (acid-catalyzed recombination of the dipyrrane) or decomposition. ${ }^{[17 f, 20]}$ 5-(Pentafluorophenyl)dipyrrane (1) combines this higher stability compared to simple meso-phenyl- or alkyl-substituted derivatives with a high susceptibility to nucleophilic substitution. ${ }^{[16]}$ Recently, the nucleophilic substitution with alcohols on PFP-dipyrrane has been described; as for other PFP substitutions a high regioselectivity for the para-position was observed. Aminesubstitution has also been used to modify PFP-substituted porphyrins with polar substituents in order to increase their PDT activity. ${ }^{[13 d]}$ Hence we were interested in investigating the suitability of $S_{N} A r$ with amines on PFP-dipyrrane. Therefore, PFP-dipyrrane $1^{[21]}$ was synthesized and reacted with several amines (Table 1). The reactions were performed in DMSO as an aprotic polar solvent which also in the literature has been employed for nucleophilic substitution with amines on PFPsubstituted compounds. ${ }^{[11,13 a, 18 \mathrm{e}]}$ In nearly all cases the corresponding amino-substituted dipyrrane was obtained in high yield; the functional groups introduced in this way comprised allyl, propargyl, azido, ${ }^{[22]}$ hydroxyl and amino. The somewhat lower yield for the azido-substituted compound $\mathbf{2 d}$ is a compromise between full consumption of the starting material and partial decomposition due to higher temperature and longer reaction times. For 1,4-dibutylamine (Table 1, entry 6 ) only a partial conversion could be achieved. However, in order to avoid side reactions only short reaction times were chosen. As for the alkoxy-substituted dipyrranes ${ }^{[16]}$ the reaction proceeded regioselectively at the para-position of the PFP-moiety which can be seen from the disappearance of the para-fluorine signal in the ${ }^{19} \mathrm{~F}$ NMR spectra of the dipyrranes. With the aminofunctionalized precursors at hand their suitability for the synthesis of porphyrinoids and BODIPYs was evaluated.
Table 1. Synthesis of amino-substituted dipyrranes 2a-f.

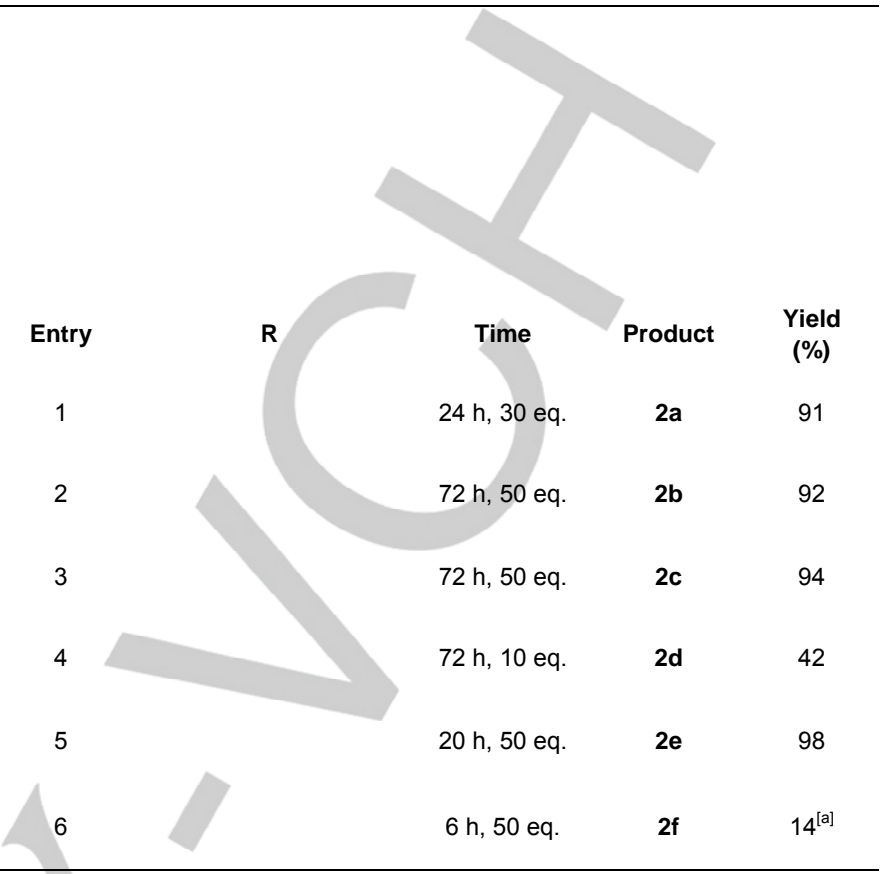

[a] $50 \%$ of the starting material 1 was recovered.

Apart from tetrapyrroles their smaller siblings, the BODIPYs, have recently found increased attention for possible applications in PDT ${ }^{[23]}$ Moreover, they are well-established as fluorescence labels for diverse biochemical applications. ${ }^{[2]}$ Employing the well-known three-step-one-pot sequence ${ }^{[25]}$ we tested with four selected examples whether the amino-functionalized dipyrranes can be used for the synthesis of the corresponding aminosubstituted BODIPYs (Scheme 1). With the exception of 2 hydroxyethylamino-substituted BODIPY $\mathbf{3 d}$ (Scheme 1), all functionalized BODIPYs were obtained in yields typical for the BODIPY synthesis sequence showing that such aminosubstituted dipyrromethanes provide a straightforward access to amino-substituted BODIPYs.<smiles>[R]Nc1c(F)c(F)c(C(c2ccc[nH]2)c2ccc[nH]2)c(F)c1F</smiles>

2b-e
1) $\mathrm{DDQ}, 5 \mathrm{~min}, 1 \mathrm{eq}$

2) DIPEA, $15 \mathrm{~min}, 7 \mathrm{eq}$

3) $\mathrm{BF}_{3} \cdot \mathrm{OEt}_{2}, 10-30 \mathrm{~min}, 11 \mathrm{eq}$

DCM, rt

$9-47 \%$<smiles>[R]Nc1nc(F)c(C(=C2c3cccn3B(F)n3cccc32)c2c(F)c(F)c(F)c(F)c2F)c(F)c1F</smiles>

3a-d
3a $\mathrm{R}=$

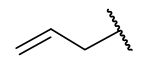
$47 \%$
3c $\mathrm{R}=$

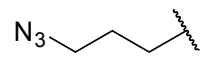
$36 \%$
3b $\mathrm{R}=$<smiles>C#CCC(C)C</smiles>
$38 \%$
3d $\mathrm{R}=$<smiles>CC(C)CCO</smiles>
$9 \%$ 
In principle, such amino-substituted BODIPYs may alternatively be obtained by the direct reaction of BODIPY 4 with amines. To test this route, the parent PFP-substituted BODIPY $\mathbf{4}$ was synthesized according to a recently published procedure. ${ }^{[16]}$ In the literature the nucleophilic substitution of the para-fluorine atom in PFP-substituted BODIPYs has been carried out on coresubstituted BODIPYs in DMF at room temperature to obtain in some cases a quantitative yield. ${ }^{[26]}$ Hence, BODIPY 4 was dissolved in DMF, $n$-butylamine (8 eq.) was added, and the mixture was stirred for one hour at room temperature. After work-up and purification by column chromatography two products were isolated. Besides the desired substitution in the para-position of the PFP-ring, an additional substitution in the alpha-position of the BODIPY core was observed (Compound $\mathbf{5 a} / \mathbf{b}$ ). In fact, no exclusive para-substitution product could be detected, either alpha- or a combined alpha- and parasubstitution occurred (for details see Supporting Information). Variation of the reaction conditions (time, temperature or solvent, see Scheme 2) had no effect on this outcome. The alphasubstitution on the BODIPY core - known as oxidative nucleophilic substitution of hydrogen (ONSH) - has first been described by Dehaen and co-workers, who used it for preparing functionalized BODIPYs. ${ }^{[27]}$

Scheme 2. Reaction of BODIPY 4 with $n$-butylamine.

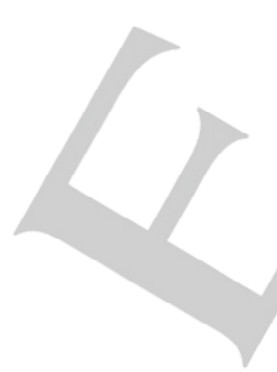

These results underline that the amino-functionalized dipyrranes 2b-e provide access to amino-substituted BODIPYs otherwise not easily accessible via direct amination.

For two of the amino-substituted BODIPYs (3a and $\mathbf{3 d}$ ) single crystals suitable for $\mathrm{X}$-ray crystallography were obtained via liquid diffusion of $\mathrm{CH}_{2} \mathrm{Cl}_{2}$ and methanol. Compound $3 \mathrm{a}$ solved with one molecule present in the asymmetric unit. The tilt angle of the BODIPY plane to that of the phenyl ring is $74.77(6)^{\circ}$. The unit cell features predominantly a head-to-head arrangement of molecules. This is aided by a hydrogen-fluorine interaction $(\mathrm{H} 1 \cdots \mathrm{F} 24)$ of 2.399(1) $\AA$ between the BODIPY moieties (Figure 1).

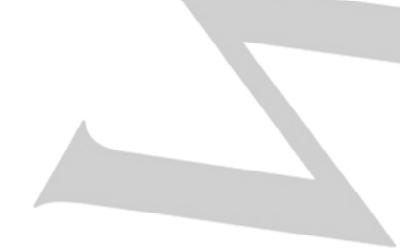

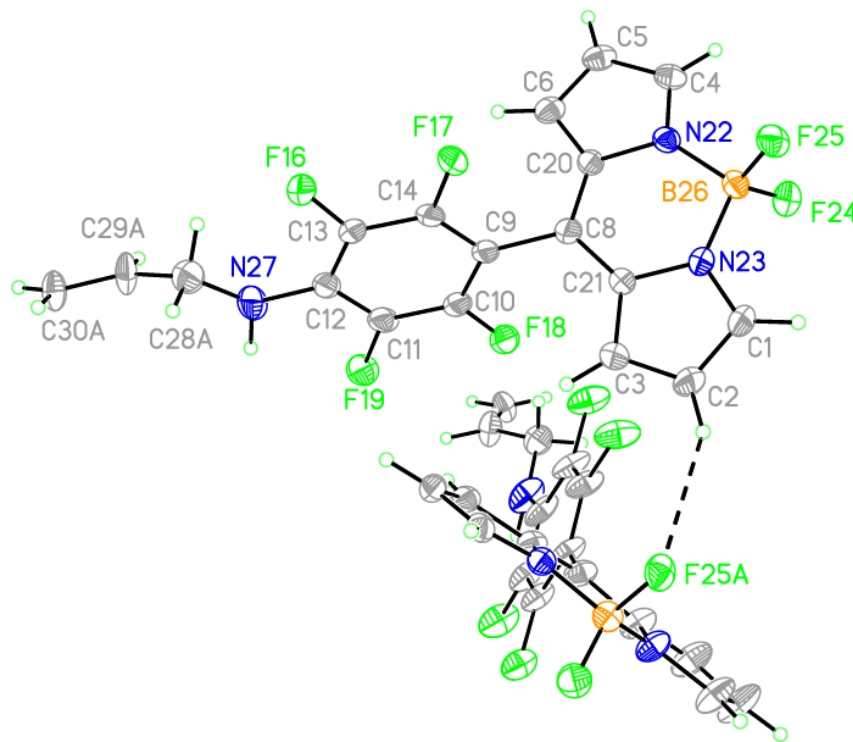

Figure 1. Molecular structure of $\mathbf{3 a}$ (thermal displacement 50\%) and illustration of the close intermolecular packing. Hydrogens atoms and disordered positions are omitted for clarity.

Compound $\mathbf{3 d}$ crystallized with one molecule in the asymmetric unit. The tilt angle of the BODIPY plane to that of the phenyl ring is $53.91(3)^{\circ}$. In the unit cell a head-to-tail overlap is exclusively observed with the BODIPY planes parallel to each other. This is aided by hydrogen bonds between N87-H87•.0090 [2.097(17) Å], which join the two tails of a molecule together. These polymeric chains consist of dimers held together by $\mathrm{F} 12-\mathrm{H} 90$ interactions (Figure 2).

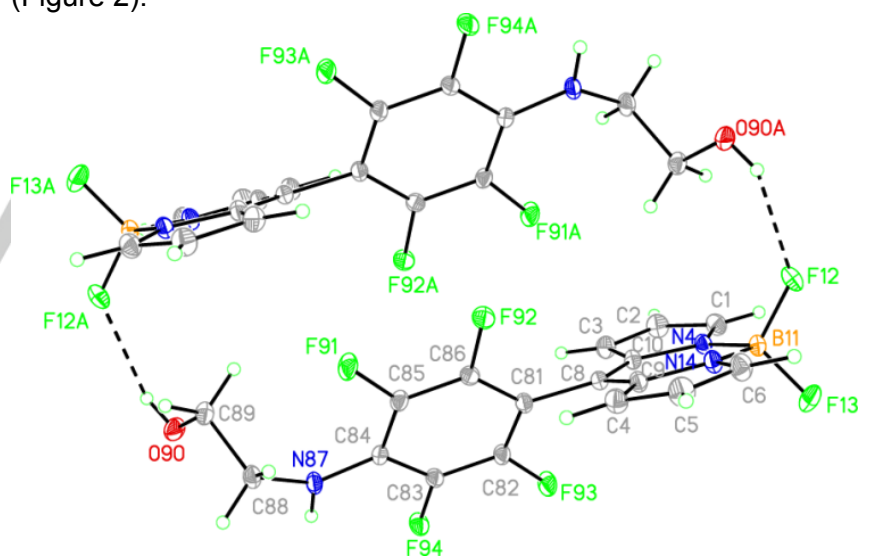

Figure 2. View of the molecular structure of $\mathbf{3 d}$ in the crystal showing the formation of $\mathrm{H} \cdots \mathrm{F}$ bonded dimers.

Alkynyl-substituted BODIPYs like $\mathbf{3} \mathbf{b}$ are suitable building blocks for further transformations, e.g., the copper(I)-catalyzed 1,3dipolar cycloaddition ('click' chemistry). ${ }^{[28]}$ Therefore, in a followup reaction the propargylamino-substituted BODIPY $\mathbf{3 b}$ was reacted with the bis(azido-propyl)-substituted corrole 6 (Scheme 3 , see Supporting Information for synthesis details of 6 ). Under standard conditions the corresponding corrole-BODIPYheterotrimer 7 with flexible propyl-linkers was isolated in $41 \%$ yield. In the reaction copper(II) sulfate had to be used in excess because copper is complexed by the corrole during the reaction forming a diamagnetic copper complex which could be 
characterized by standard NMR measurements. ${ }^{29}$ For similar 'click' connections in the literature also the preceding complexation with copper has been described. ${ }^{[29 a]}$ Conjugates like 7 have recently found attention as compounds for studying energy or electron transfer processes and as possible compounds for optoelectronic devices. ${ }^{30}$
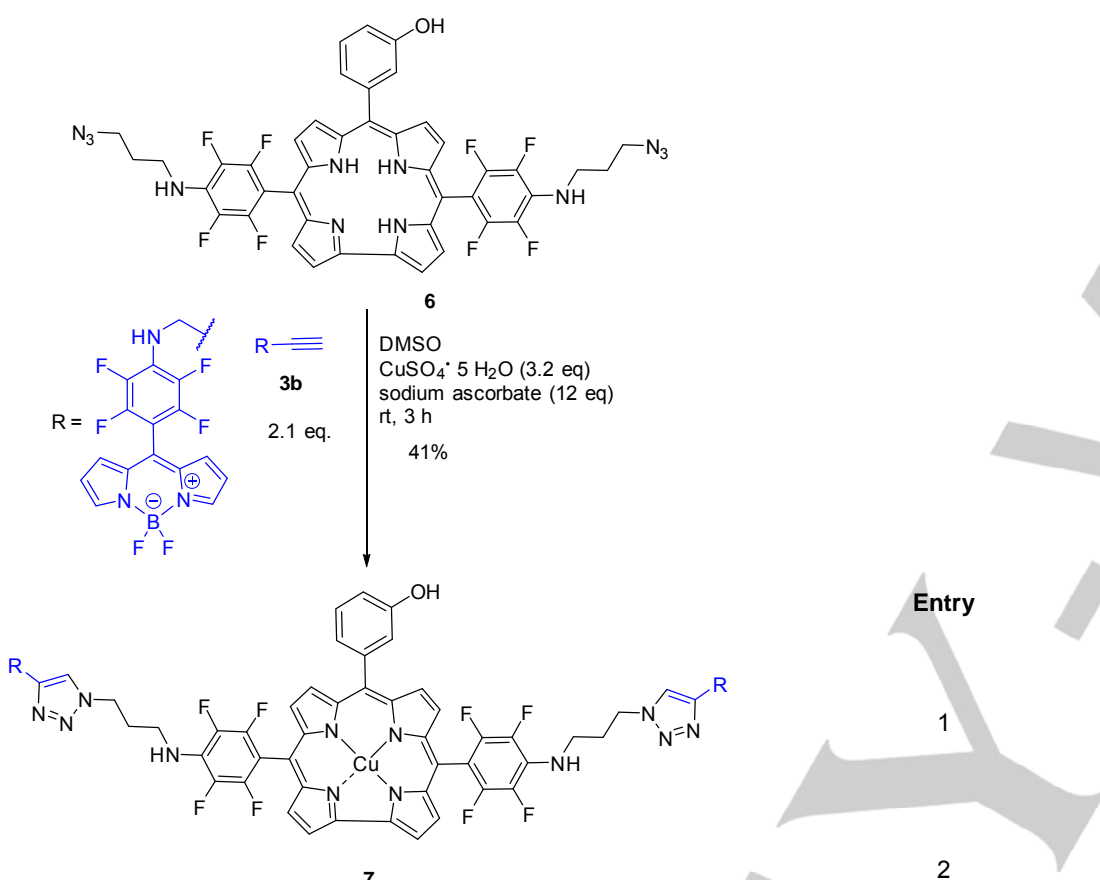

$\mathbf{R}$

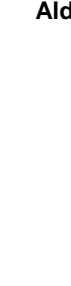

$8 a$
8 Aldehyde
$8 b$

Product
(Corrole)

Yield of $A_{2} B-$ corrole (\%)

10

Scheme 3. Click-reaction of bis(3-azidopropyl)-substituted corrole 6 with alkynyl-substituted BODIPY $\mathbf{3 b}$.

The next step was the application of the dipyrranes in the synthesis of porphyrinoids. First, the synthesis of corroles was investigated starting with the amino-substituted dipyrranes (Table 2). As we were interested in connecting them to other molecular moieties, the alkynyl-substituted dipyrrane 2c was chosen as an example. Principally following Gryko's method of corrole synthesis ${ }^{[17 \mathrm{e}]}$ the amount of acid for the condensation step with the aldehyde was increased in this case due to the (expected) protonation of the amine. In the first example pentafluorobenzaldehyde (8a) was reacted with the alkynylsubstituted dipyrrane 2c. After purification the desired corrole 9a was obtained in $10 \%$ yield (Table 2 , entry 1 ). The possible byproduct, the $\mathrm{A}_{2} \mathrm{~B}_{2}$-porphyrin, was not detected in this case. Also with the other two aldehydes the corresponding $A_{2} B$ corroles were obtained in acceptable yields. In the case of 3acetoxybenzaldehyde, the $A_{2} B_{2}$-porphyrin was obtained as a byproduct (Table 2, entry 2).

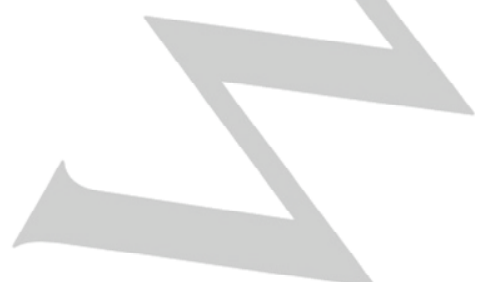
3 8c

9c
10
${ }^{\text {[a] }}$ The $A_{2} B_{2}$-porphyrin was isolated as a by product.

The successful transformation of the amino-substituted dipyrranes into corroles illustrates their capability of reacting in acid-catalyzed condensation reactions leading to tetrapyrroles. This is unexpected insofar as it might have been envisaged that the basic amino substituent, in contrast to the alkoxysubstituent, ${ }^{[16]}$ may interfere with the acid catalysis employed during porphyrinoid synthesis. Aminophenyl-substituted porphyrins are therefore usually obtained by reduction of the respective nitrophenyl-substituted porphyrins or by deprotection of acetamidophenyl-substituted porphyrins and not by direct condensation with pyrrole. ${ }^{[31]}$

Dipyrranes are also regularly employed for the preparation of trans- $\mathrm{A}_{2} \mathrm{~B}_{2}$-porphyrins. ${ }^{[8 \mathrm{a}, 17 \mathrm{~g}]}$ However, the use of mesofunctionalized dipyrranes for condensation reactions to $A_{2} B_{2}$ porphyrins is limited especially for dipyrranes carrying sensitive functional groups. ${ }^{[\mathrm{8a}, 17 \mathrm{~g}, 32,33]}$ To examine scope and limitation of the reaction the conversion of several amino- and alkoxysubstituted dipyrranes into trans- $\mathrm{A}_{2} \mathrm{~B}_{2}$-porphyrins was investigated (Table 3 ). The alkoxy-substituted dipyrranes 10a-c 
were synthesized according to literature procedures. ${ }^{[16]}$ Pentafluorobenzaldehyde $\mathbf{8 a}$ was chosen as the second aldehyde as it has the advantage of introducing an additional PFP-substituent susceptible to subsequent $S_{N} A r$-reactions. As catalysts for these condensations, TFA and $\mathrm{BF}_{3} \cdot \mathrm{OEt}_{2}$ are prominent. ${ }^{[8 \mathrm{a}, 34]}$ For electron-deficient aldehydes, e.g., pentafluorobenzaldehyde, $\mathrm{BF}_{3} \cdot \mathrm{OEt}_{2}$ is favored due to higher yields of porphyrin. ${ }^{[35]}$ Therefore, we decided to first employ this catalyst for the condensation.

\begin{tabular}{|c|c|c|c|c|c|c|c|c|}
\hline Entry & $\mathbf{R}$ & Acid catalyst & Product $\left(A_{2} B_{2}\right)$ & $A_{2} B_{2}(\%)$ & $A_{4}(\%)$ & $A_{3} B(\%)$ & $\mathrm{AB}_{3}(\%)$ & $\mathrm{B}_{4}(\%)$ \\
\hline 1 & & $\mathrm{BF}_{3} \cdot \mathrm{OEt}_{2}$ & & $6^{[\mathrm{a]}]}$ & - & - & 18 & 2 \\
\hline 2 & & TFA & $11 \mathrm{a}$ & 8 & - & $<1$ & - & - \\
\hline 3 & & $\mathrm{BF}_{3} \cdot \mathrm{OEt}_{2}$ & & $3^{[a]}$ & 4 & - & - & - \\
\hline 4 & & TFA & מגו & 2 & - & - & - & - \\
\hline 5 & & $\mathrm{BF}_{3} \cdot \mathrm{OEt}_{2}$ & $11 \mathrm{c}$ & 2 & - & 2 & 12 & 4 \\
\hline 6 & & $\mathrm{BF}_{3} \cdot \mathrm{OEt}_{2}$ & $11 d$ & 13 & 2 & 7 & 5 & - \\
\hline 7 & & $\mathrm{BF}_{3} \cdot \mathrm{OEt}_{2}$ & $11 \mathrm{e}$ & 12 & - & Traces & - & - \\
\hline
\end{tabular}

${ }^{[a]}$ Mixture of isomers.

However, in particular for the two amino-substituted dipyrranes in addition to the desired $\mathrm{A}_{2} \mathrm{~B}_{2}$-porphyrins, other porphyrins were formed as by-products due to 'scrambling', ${ }^{[36,37]}$ for the dipyrranes $\mathbf{2 b}$ and $\mathbf{1 0 a}$ in amounts larger than the desired product (Table 3, entries 1 and 4). This observation is in accordance with a recent publication by Arunkumar and coworkers who also observed large amounts of scrambling products in the condensation reaction of 5-(4-cyanophenyl)dipyrrane and $\mathbf{8 a}$ with $\mathrm{BF}_{3} \cdot \mathrm{OEt}_{2}$ as catalyst. ${ }^{[38]}$ Moreover, for product $11 \mathbf{a}$ and $11 \mathbf{b}$ the $\mathrm{A}_{2} \mathrm{~B}_{2}$-porphyrins were isolated as an inseparable mixture of the cis- and trans- $\mathrm{A}_{2} \mathrm{~B}_{2}$-porphyrin. Therefore, the reaction of amino-functionalized dipyrrane $\mathbf{2 b}, \mathbf{e}$ and aldehyde $8 \mathbf{a}$ was repeated with TFA as the acid catalyst (Table 3 , entry 2). This time a lower amount of scrambling products was observed with the desired trans- $\mathrm{A}_{2} \mathrm{~B}_{2}$-porphyrin being the main product. This does suggest that for the condensation of the amino-substituted dipyrranes under equilibrium conditions TFA is the preferable catalyst.
In the next step, selected trans- $\mathrm{A}_{2} \mathrm{~B}_{2}$ porphyrins were subjected to a subsequent nucleophilic substitution of the two free parafluorine atoms with alcohols and amines (Table 4). In all cases the tetrafunctionalized porphyrins carrying two different kinds of substituents in a specific arrangement could be obtained. In the reaction of different amines with porphyrin 11c and 11d carrying allyloxy and propargyloxy substituents in the 5,15 positions, respectively - an unexpected side reaction was observed.

Under the reaction conditions (base, high temperature, long reaction times) the propargyloxy and the allyloxy substituents were in part split off generating the respective para-hydroxysubstituted compound (see Supporting Information for details). For the propargyloxy substituent this side reaction may be rationalized by a base-promoted rearrangement leading to the corresponding alkoxyallene that decomposes under the reaction conditions; ${ }^{[39]}$ a similar conversion of the propenyl group is conceivable. 


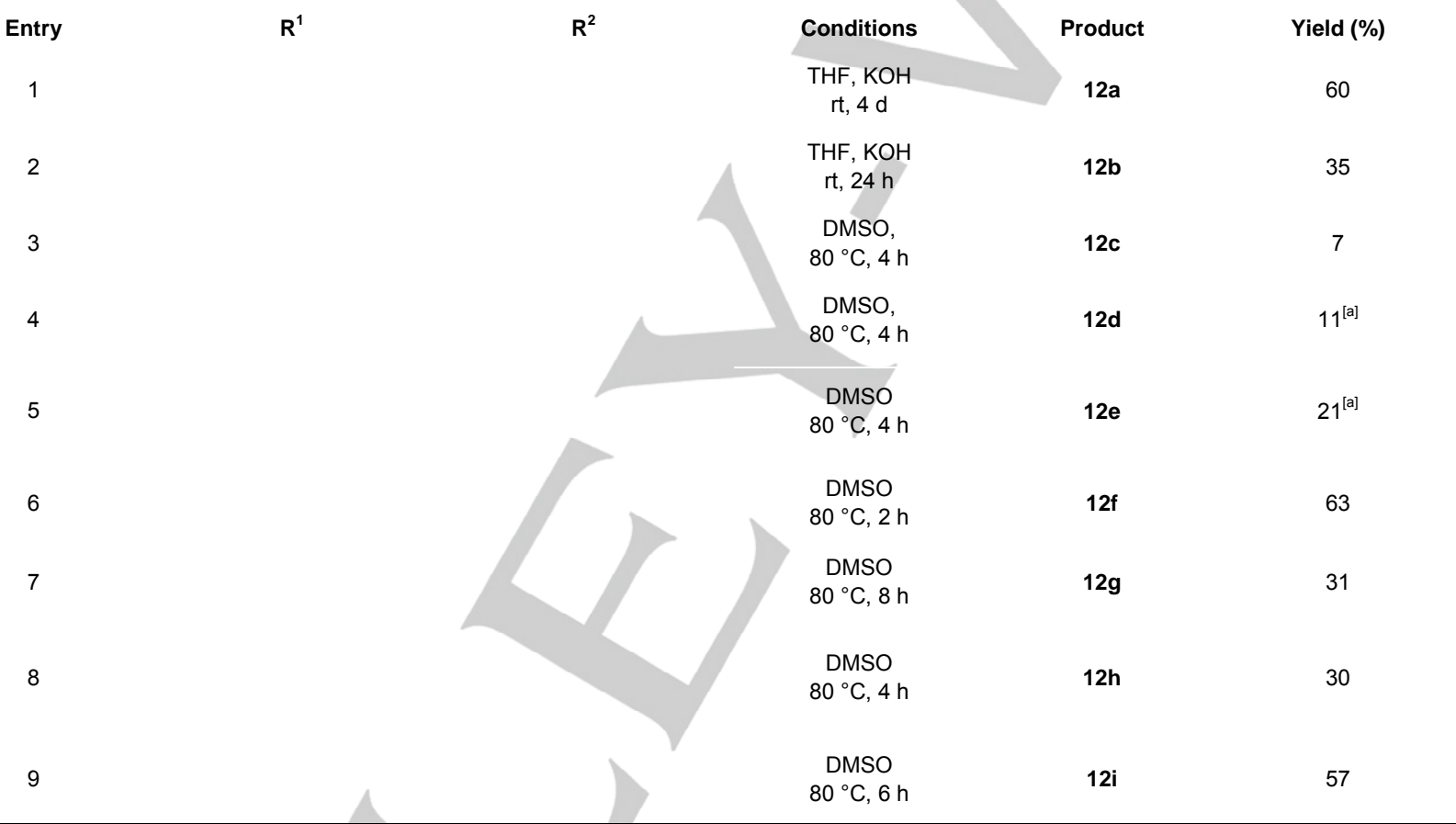

${ }^{[a]}$ Partial split off of the propargyloxy and the allyloxy substituent was observed. For further information see Supporting Information.

During the condensation reaction of the amino- and alkoxyfunctionalized dipyrranes to trans- $\mathrm{A}_{2} \mathrm{~B}_{2}$-porphyrins a considerable amount of the corresponding $\mathrm{AB}_{3}$-porphyrins carrying one PFP group had been obtained (cf. Table 4, entries 1 and 4). Therefore, the possibility of mono-functionalization with alcohols and amines was explored with these compounds (Table 5, compounds $\mathbf{1 3} \mathbf{a}, \mathbf{b})$. As expected, the reactions proceeded well and the desired tetra-functionalized $\mathrm{AB}_{3}-$ porphyrins could be obtained in all cases (Table 5, entries 1-5). 


\begin{tabular}{|c|c|c|c|c|}
\hline Entry & 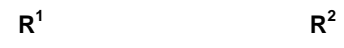 & Conditions & Product & Yield (\%) \\
\hline 1 & & $\begin{array}{c}\text { DMSO } \\
80^{\circ} \mathrm{C}, 4 \mathrm{~h}\end{array}$ & $14 a$ & 53 \\
\hline 2 & & $\begin{array}{c}\mathrm{THF}, \mathrm{KOH} \\
\text { rt, } 3 \mathrm{~d}\end{array}$ & $14 \mathrm{~b}$ & $63^{[a]}$ \\
\hline 3 & & $\begin{array}{c}\mathrm{THF}, \mathrm{KOH} \\
\mathrm{rt}, 4 \mathrm{~d}\end{array}$ & $14 \mathrm{c}$ & $43^{[b]}$ \\
\hline 4 & & $\begin{array}{c}\mathrm{THF}, \mathrm{KOH} \\
\mathrm{rt}, 3 \mathrm{~d}\end{array}$ & $14 d$ & 34 \\
\hline 5 & & $\begin{array}{c}\text { THF, KOH } \\
\quad r t, 4 \mathrm{~d}\end{array}$ & $14 \mathrm{e}$ & 43 \\
\hline
\end{tabular}

${ }^{[a]}$ As a by-product the compound with $\mathrm{R}^{2}=\mathrm{OH}$ was isolated in $24 \%$ yield. ${ }^{[b]}$ Starting material was recovered in $26 \%$ yield. position. ${ }^{[18 c, 42]}$ We set out to synthesize unsymmetrical

After successful synthesis of BODIPYs, corroles and porphyrins starting from amino- and alkoxy-substituted dipyrranes we were also interested in applying this concept to the synthesis of expanded porphyrin systems such as hexaphyrins as prominent examples of expanded porphyrins. ${ }^{[18 b, 40]}$ The mesohexakis(pentafluorophenyl)-substituted [26]hexaphyrin was first reported by Cavaleiro et al. ${ }^{[41]}$ and later its chemistry and synthesis was investigated in detail by Osuka and coworkers. ${ }^{[18 c]}$ Most work with hexaphyrins and other expanded porphyrin systems has been performed with compounds carrying only identical substituents. ${ }^{[40 a]}$ Hexaphyrins involving different substituents are rare. ${ }^{[18 c, 42,43]}$ The synthetic scope of [26] hexaphyrin was at first limited to reactions of pyrrole with a few fluorinated aromatic aldehydes. ${ }^{[44]}$ In 2003 , Osuka and coworkers published a synthesis starting from PFP-dipyrrane and various aldehydes, involving mostly alkyl- and alkoxy-substituted benzaldehydes. ${ }^{[18 c]}$ The modification of hexaphyrins is also possible via $\mathrm{S}_{N} A r-$ reactions at the para-position of meso-PFP substituents using alcohols and amines as nucleophiles. ${ }^{[9,45,46]}$ However, the direct introduction of functional groups via the dipyrrane precursors is a more attractive synthetic approach, specifically for the synthesis of unsymmetrically substituted hexaphyrins. Osuka et al. were the first to synthesize hexaphyrins with two different kinds of substituents in the meso- hexaphyrins starting from alkoxy- and amino-substituted dipyrranes and aldehyde 8a. For this purpose the aminosubstituted dipyrrane $2 \mathbf{e}$ and the alkoxy-substituted dipyrranes 10b and $\mathbf{1 5}$ were selected which were synthesized according to the literature. ${ }^{[41]}$ Following the method by Osuka et al. ${ }^{[43]}$ $\mathrm{BF}_{3} \cdot \mathrm{OEt}_{2}$ was used as the catalyst. With the two alkoxysubstituted dipyrranes $\mathbf{1 0 b}$ and 15 only the formation of the purple [26] hexaphyrins $\mathbf{1 6 a}$ and $\mathbf{1 6 b}$ was observed (Scheme 4). On the other hand, with the amino-substituted dipyrrane $2 \mathbf{e}$ the blue [28] hexaphyrin 23 was isolated (Scheme 4). The outcome of two hexaphyrins with a different $\pi$-system is in accordance with observations in literature. ${ }^{[9 g, 45,46]}$ It has been described that the reaction of meso-hexakis(pentafluorophenyl)hexaphyrin with amines yielded the substituted [28]hexaphyrin, whereas the reaction with alcohols gave the expected substituted [26]hexaphyrin. ${ }^{[99,45,46]}$ Interestingly, the [28]hexaphyrin 17 is obtained though the amino-substituent is already incorporated in the dipyrrane, suggesting that the simple presence of amino groups in the reaction accounts for the formation of the [28]hexaphyrin system. In the synthesis of hexaphyrins byproducts such as porphyrin, $\mathrm{N}$-fused pentaphyrin, heptaphyrin, octa- and nonaphyrin have often been isolated. ${ }^{[39 c, 44]}$ In the synthesis of $16 \mathbf{a}, \mathbf{b}$ and 17 in all cases a small amount of the respective trans- $\mathrm{A}_{2} \mathrm{~B}_{2}$-porphyrin was isolated in $3-6 \%$ yield. 

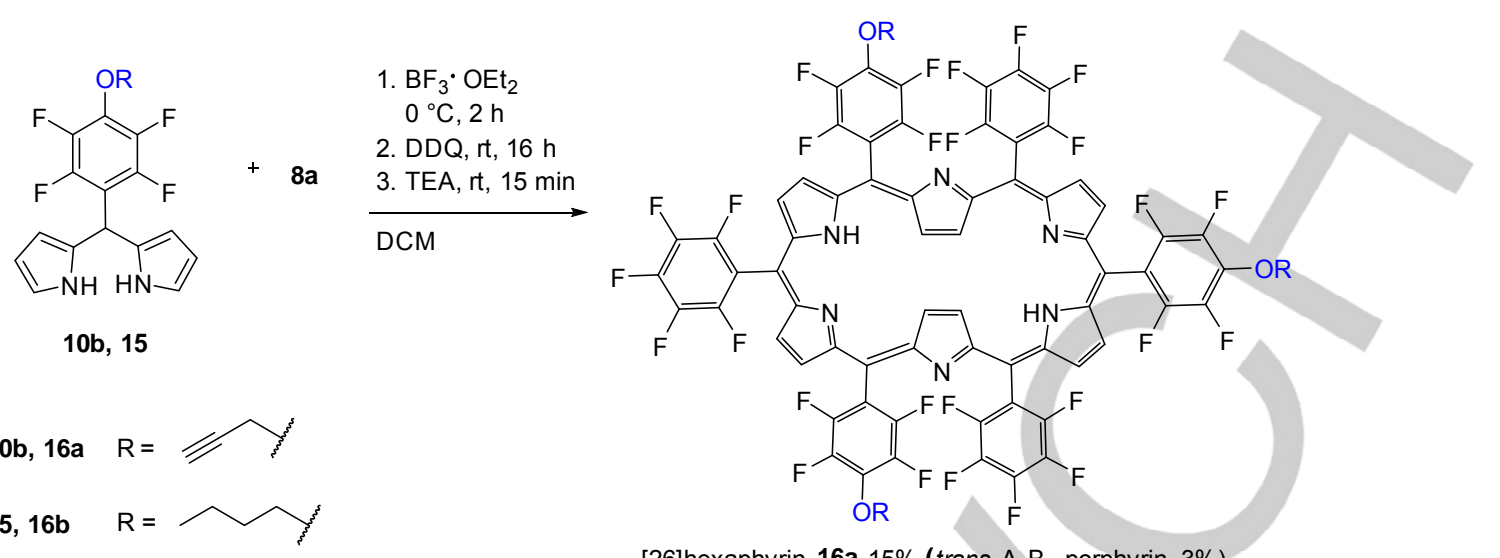

[26]hexaphyrin 16a $15 \%$ (trans $-\mathrm{A}_{2} \mathrm{~B}_{2}$-porphyrin $3 \%$ )

16b $42 \%$ (trans- $\mathrm{A}_{2} \mathrm{~B}_{2}$-porphyrin $6 \%$ )

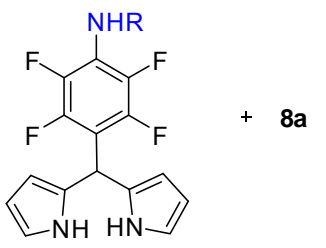

$2 e$

$$
\mathrm{R}=\mathrm{HO}^{\xi}
$$

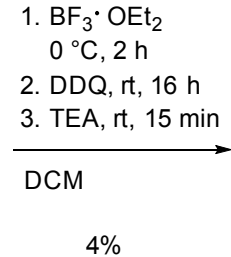

$4 \%$

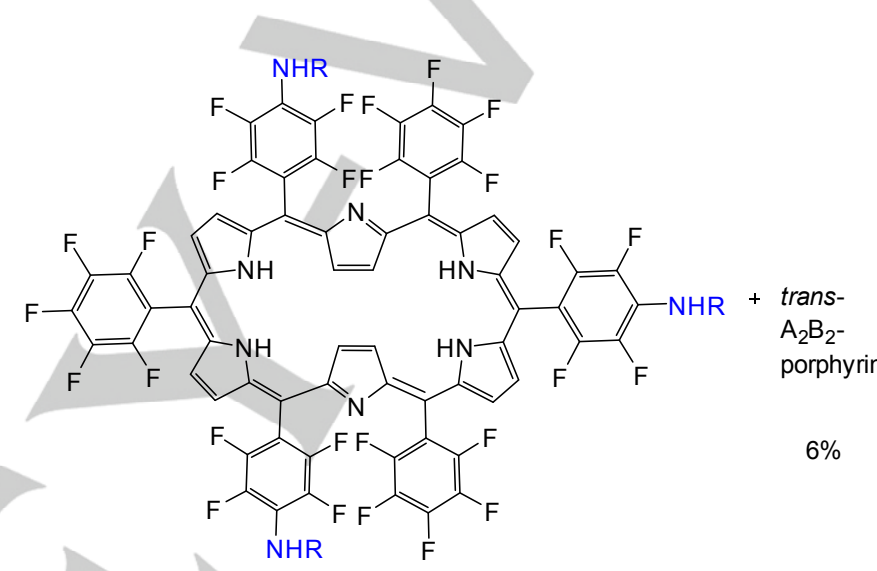

[28]hexaphyrin 17

Scheme 4. Synthesis of [26]hexaphyrins $16 \mathbf{a}, \mathbf{b}$ and [28]hexaphyrin 17 starting from pre-functionalized dipyrranes and aldehydes $8 \mathbf{a}$.

The introduction of alternating para-substituted fluorophenyl moieties was verified by ${ }^{19} \mathrm{~F}$ NMR spectroscopy in comparison to the ${ }^{19} \mathrm{~F}$ NMR data of the basic meso-hexakis(pentafluorophenyl)substituted [26]hexaphyrin. ${ }^{[47]}$ Characteristically, in the ${ }^{19} \mathrm{~F}$ NMR spectrum two para-fluorine signals corresponding to only three fluorine atoms (of the PFP-moieties) can be detected, which ascertains the introduction of the pre-functionalized dipyrrane. Beside these two signals of the para-fluorine atoms, signals for the ortho- und meta-position, four signals each, are visible (Figure 3).

The alternating position of the two substituents can also be confirmed by the ${ }^{1} \mathrm{H}-\mathrm{NMR}$ spectrum, which shows four sets of doublets, indicative of the symmetry (see Supporting Information).
The difference between [26]hexaphyrins and [28]hexaphyrins is clearly visible in the ${ }^{1} \mathrm{H}$ NMR spectra (see Supporting Information). In the ${ }^{1} \mathrm{H}$ NMR spectrum of [26] hexaphyrin 16a, the inner $\mathrm{NH}$ protons appear as a broad signal at $-2.06 \mathrm{ppm}$, the inner pyrrolic $\beta$-protons appear at $-2.41 \mathrm{ppm}$ and the outer pyrrolic $\beta$-protons appear as four sharp doublets at 9.09, 9.14, 9.42 , and $9.45 \mathrm{ppm}$, respectively, corresponding to the [4n+2] Hückel aromaticity of the compound. In contrast, the [28]hexaphyrin 17 exhibits no signals at negative $\delta$ values (not shown, see Supporting information). This compound shows a signal for the inner pyrrolic $\beta$-protons at $2.56 \mathrm{ppm}$ and the inner $\mathrm{NH}$ protons appear as a broad singlet at $4.48 \mathrm{ppm}$. The outer pyrrolic $\beta$-protons are observed as two sharp doublets at 7.69 and 7.91, respectively, and one multiplet at 7.81 . 


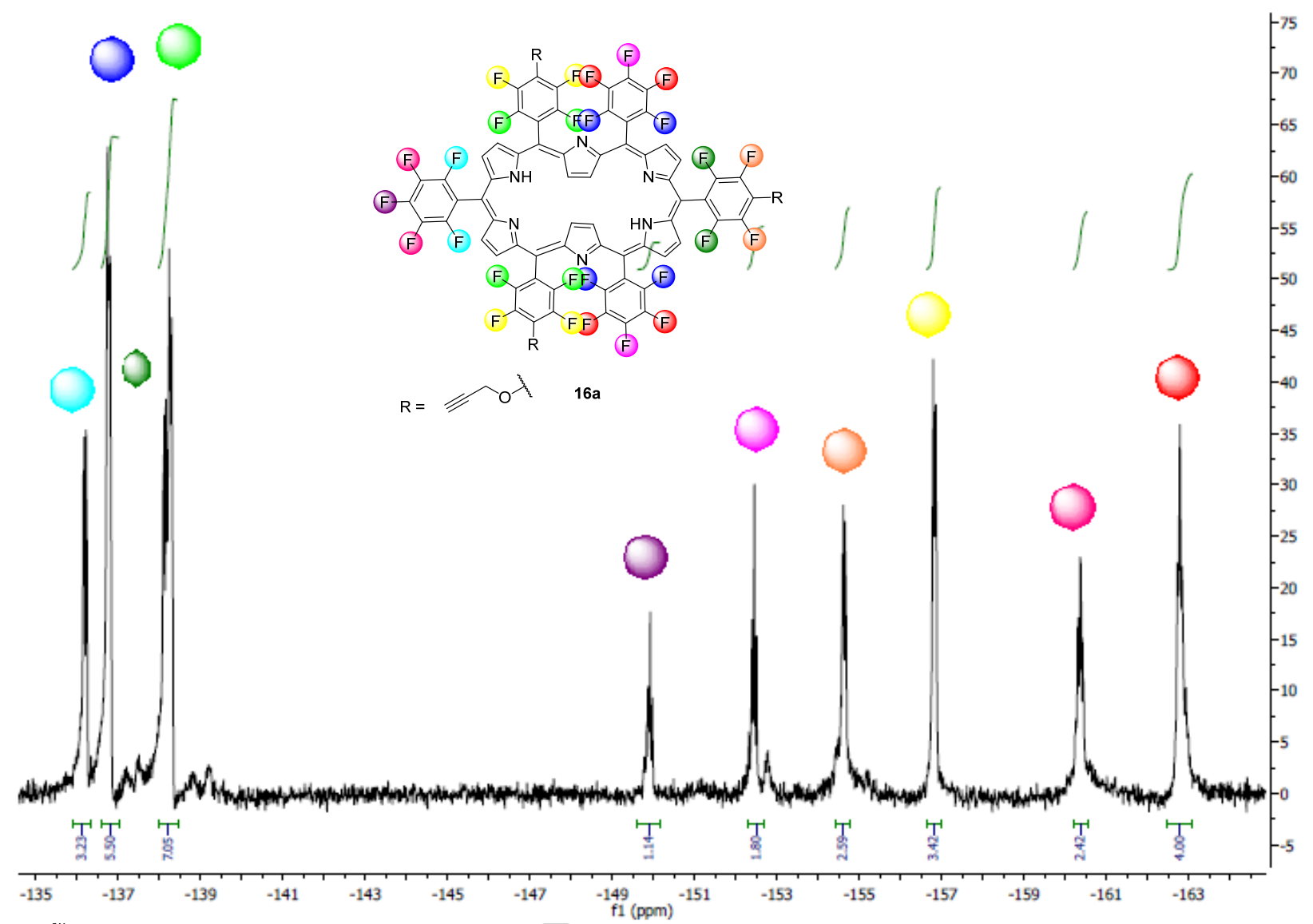

Figure 3. ${ }^{19} \mathrm{~F}$ NMR spectrum $\left(\mathrm{CDCl}_{3}, 376 \mathrm{MHz}\right)$ of [26]hexaphyrin 16a.

\section{Absorption spectroscopy}

All new compounds were fully characterized by NMR spectroscopy and mass spectrometry, additionally the absorption spectra of all new chromophores were measured. In summary, the synthesized compounds - BODIPYs, corroles, $\mathrm{A}_{2} \mathrm{~B}_{2^{-}}$and $\mathrm{A}_{3} \mathrm{~B}$-porphyrins, [26]hexaphyrins and the [28]hexaphyrin - exhibited absorption properties typical for the respective chromophore class, with the BODIPYs also exhibiting strong fluorescence at $\sim 530 \mathrm{~nm}$. The UV/Vis absorption of the compounds spans from $\sim 380$ to $\sim 800 \mathrm{~nm}$ (Figure 4), with the most intensive absorption band ranging from $\sim 410 \mathrm{~nm}$ for the porphyrins to $\sim 600 \mathrm{~nm}$ for the [28]hexaphyrin. Within one group of chromophores (porphyrins, corroles, and BODIPYs, respectively) the different substituents also do not change absorption properties significantly, i.e. the exchange of the parafluorine by alkoxy or amino moieties seems to have only a very limited effect on the chromophore compared to the basic PFPsubstituted compounds. This limited effect has also been observed for porphyrins where more than one fluorine atom in the PFP moieties has been exchanged. ${ }^{[48]}$ It can mainly be attributed to the tilt angle of the substituted phenyl ring relative to the chromophore plane (cf. e.g. above the x-ray data of the BODIPYs) which lowers the electronic interaction.

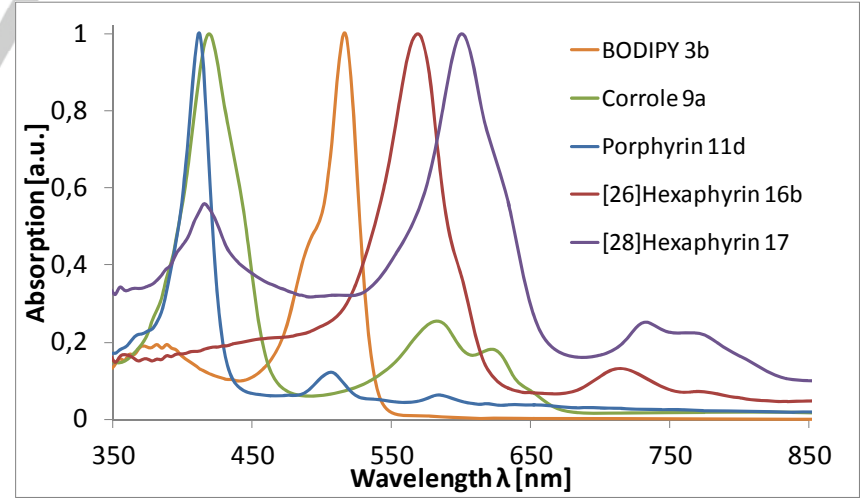

Figure 4. Absorption spectra (normalized) of compounds 3b, 9a, 11d, 16b and 17.

The nucleophilic substitution with amines (and alcohols) on PFPsubstituted dipyrranes thus allows an efficient synthesis of functionalized chromophores without affecting the basic absorption properties. 


\section{Cell testing}

By combining the pre-functionalization with amines of the dipyrrane precursor with the post-functionalization of the formed porphyrin, specifically substituted trans- $\mathrm{A}_{2} \mathrm{~B}_{2}$-porphyins could be prepared. Due to their polar substituents $(\mathrm{OH}$ and $\mathrm{NH})$ in combination with the hydrophobic porphyrin skeleton these exhibit a 'medium' polarity which is also found in clinically applied photosensitizers such as Temoporfin ${ }^{[49]}$ or TOOKAD. ${ }^{[50]}$ Moreover, trans- $\mathrm{A}_{2} \mathrm{~B}_{2}$-porphyins carrying polar substituents have been reported to exhibit a high PDT activity. ${ }^{[51]}$ Hence, compounds 12e, 12h, 12i and the bisamino-substituted precursor 11b were selected for testing against four tumor cell lines (Figure 5a-d): Human epidermoid carcinoma cell lines A431 and A253, respectively, squamous carcinoma cell line CAL-27, and colorectal adenocarcinoma cell line HT29. In brief, cells were incubated for $24 \mathrm{~h}$ with a solution of either 0,2 or 10 $\mu \mathrm{mol} / \mathrm{L}$ concentration of the photosensitizer and medium, then the medium was changed (to assure that only photosensitizer taken up by the cells contributes to the effect) and the cells were irradiated with light of $652 \mathrm{~nm}$ (corresponding to the longest wavelength absorption band of the porphyrins); after another incubation period $(24 \mathrm{~h})$ with medium the vitality of the cells was determined using the XTT-test (see experimental section for details).

As can be seen in Figure 5 none of the four compounds exhibited any significant dark toxicity at the concentrations investigated (Figure 5a-d, left side, DT = dark toxicity, i.e. toxicity in the absence of light). Regarding phototoxicity, the squamous carcinoma cell line CAL-27 seems to be especially sensitive to PDT, as a pronounced phototoxicity is observed for all four compounds at $10 \mu \mathrm{mol} / \mathrm{L}$ and a lower phototoxic effect already a $2 \mu \mathrm{mol} / \mathrm{L}$ for $\mathbf{1 1 b}, \mathbf{1 2 h}$, and $\mathbf{1 2 i}$. For the other three cell lines (A431, A253, HT29), apparently no phototoxicity is found at the lower concentration $(2 \mu \mathrm{mol} / \mathrm{L})$. With $10 \mu \mathrm{mol} / \mathrm{L}$ of photosensitizer, all three tetrafunctionalized trans- $\mathrm{A}_{2} \mathrm{~B}_{2^{-}}$ porphyrins $(\mathbf{1 2 e}, \mathbf{1 2} \mathrm{h}$, and $12 \mathrm{i})$ exhibit strong phototoxicity in the A431, A253, and HT29 cell line (comparing the cell viability at 10 $\mu \mathrm{mol} / \mathrm{L}$ of photosensitizer without and with light). The precursor 11b, carrying two polar groups and two unfunctionalized PFP groups, however, shows no sign of photoxicity in these three cell lines. As the concentrations for which a phototoxic effect is observed with $\mathbf{1 2} \mathbf{e}, \mathbf{1 2} \mathrm{h}$, and $\mathbf{1 2} \mathrm{i}$ are still quite high, compared to clinically applied photosensitizers like Temoporfin, ${ }^{[13 d]}$ further structure optimization will be necessary. However, these cell testing results suggest that the nucleophilic substitution with amines and alcohols on PFP-substituted compounds can be used to fine-tune the properties of porphyrins towards a higher amphiphilicity and membrane affinity. ${ }^{[7,52]}$ Currently, further substitution patterns on the porphyrins are investigated to increase this membrane affinity.
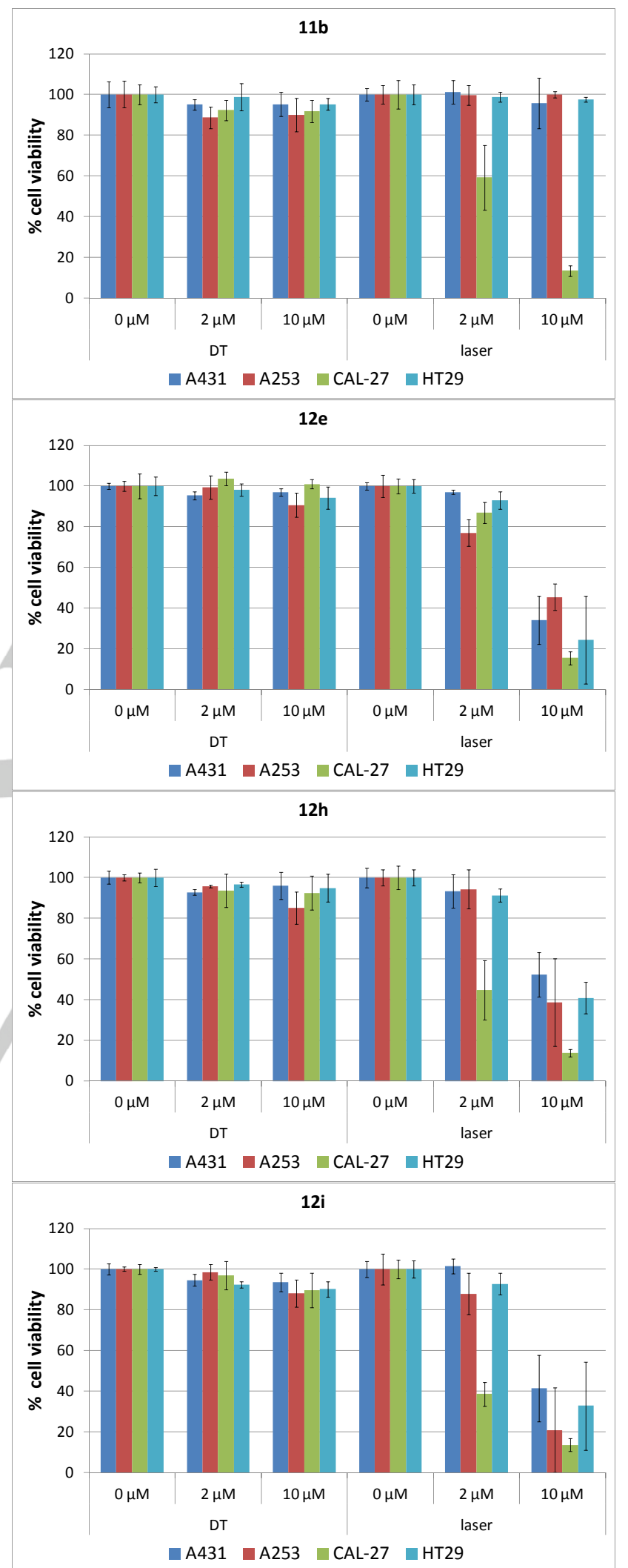

Figure 5a-d. Cell testing of compounds 11b, 12e, 12h, and 12i against A431, A253, CAL-27, and HT29 tumor cells (24 h incubation; DT: dark toxicity; laser: laser irradiation $652 \mathrm{~nm} 50 \mathrm{~J} / \mathrm{cm}^{2}$ ). 


\section{Conclusions}

In conclusion, we have developed a new and flexible access to amino-substituted porphyrinoids employing 4-amino-substituted tetrafluorophenyl-dipyrranes. It is shown that the dipyrromethane precursor, PFP-dipyrrane, readily reacts with amines affording the corresponding amino-substituted dipyrromethanes in high yields. These pre-functionalized dipyrromethanes were transformed into BODIPYs, carrying e.g. an alkyne moiety which was used in a subsequent copper(I)-catalyzed 1,3-dipolar cycloaddition to form a trimeric corrole-BODIPY conjugate. The amino-substituted dipyrranes were - in combination with a second aldehyde - also successfully employed in condensation reactions towards specifically substituted $A_{2} B$-corroles and trans- $A_{2} B_{2}$-porphyrins and even for the synthesis of novel $A_{3} B_{3}$ hexaphyrins. When combined with pentafluorobenzaldehyde additional reactive para-positions are introduced, which were used for subsequent nucleophilic aromatic substitutions. Finally, it was demonstrated that the trans- $\mathrm{A}_{2} \mathrm{~B}_{2}$-porphyrins carrying polar hydroxy/amino substituents exhibit in vitro PDT activity against several tumor cell lines.

\section{Experimental Section}

\section{General}

The nomenclature and numbering $\left({ }^{13} \mathrm{C}\right.$ and ${ }^{19} \mathrm{~F}$ NMR spectra) are in accordance with IUPAC recommendations. THF and DMSO used as solvents for the reactions were stored over molecular sieves. All liquid reagents were added through syringes. Purchased reagents were used as received without further purification. All reactions were monitored by TLC analysis. A variable UV detector $(\lambda=254 / 366 \mathrm{~nm})$ was used for detection. The preparative purification of mixtures by column chromatography was conducted on silica gel (60 M, 40-63 $\mu \mathrm{m})$. The yields refer to analytically pure compounds. NMR spectra were recorded on a 400,500 and $700 \mathrm{MHz}$ instruments, respectively. Chemical shifts are given in parts per million $(\mathrm{ppm})$ relative to the resonance of the solvent. As deuterated solvents chloroform $(\delta=7.26,77.0 \mathrm{ppm})$ and acetone $(\delta=2.05,29.0 \mathrm{ppm})$ were used. Integrals are in accordance to assignments and coupling constants are given in hertz $(\mathrm{Hz})$. All ${ }^{13} \mathrm{C}-\mathrm{NMR}$ spectra are proton decoupled. In the ${ }^{13} \mathrm{C}$ NMR spectra of the porphyrinoids not all expected ${ }^{13} \mathrm{C}$ NMR signals could be observed; especially the signal intensity of the a-carbon atoms (carrying no hydrogen) was sometimes too low to be detected. The multiplicity is indicated as follows: $s$ (singlet), br s (broad singlet), $d$ (doublet), $t$ (triplet), $\mathrm{m}$ (multiplet), $\mathrm{m}_{\mathrm{c}}$ (centered multiplet) dd (doublet of doublets), $t d$ (triplet of doublets). The ortho- and meta-fluorine signals in the ${ }^{19} \mathrm{~F}$ NMR spectra of the substituted tetrafluorophenyl moieties exhibit the $A, A^{\prime} B, B^{\prime}$ and $A, A^{\prime} X, X^{\prime}$ coupling pattern typical for para-substituted aromatic compounds, in the ${ }^{19} \mathrm{~F}$ NMR spectra these signals are denoted as $m_{c}$. HRMS analyses were performed by ESI-TOF, the solvent flow rate was adjusted to $4 \mu \mathrm{L} / \mathrm{min}$ and spray voltage was set to $4 \mathrm{kV}$. Drying gas flow rate was set to $15 \mathrm{psi}(1 \mathrm{bar})$ and all other parameters were adjusted for a maximum abundance of the respective $[\mathrm{M}+\mathrm{H}]^{+}$. Melting points are uncorrected. Compounds $1,{ }^{[21]} 4,{ }^{[16]} 3$-azidopropyl-1-amine, ${ }^{[22]} 10 \mathrm{a}-\mathrm{c}^{[16]}$ and $\mathbf{1 5}^{[16]}$ were prepared according to the literature.

\section{General Procedures}

General procedure for synthesis of substituted dipyrranes. A mixture of PFP-dipyrrane and amine in dry DMSO was stirred at $80^{\circ} \mathrm{C}$ for the specific time given for each individual experiment in table 1. After the indicated time the mixture was diluted with DCM and washed several times with water. The organic layer was dried with sodium sulfate, filtered and evaporated to dryness. The crude product was purified by silica ge column chromatography (the specific solvent mixture for each compound is given in the Supporting Information). The product was isolated and analyzed by ${ }^{1} \mathrm{H},{ }^{13} \mathrm{C},{ }^{19} \mathrm{~F}$ NMR analysis and HRMS.

General procedure for synthesis of substituted BODIPYs. Under argon atmosphere the amino-substituted dipyrrane was dissolved in DCM, DDQ was added and the mixture stirred at rt temperature for $5 \mathrm{~min}$ After addition of DIPEA and stirring for another $15 \mathrm{~min}$, finally $\mathrm{BF}_{3} \cdot \mathrm{OEt}_{2}$ was added and the reaction stirred for $20 \mathrm{~min}$. The reaction was stopped by the addition of water, washed with water several times and the organic layer was dried with sodium sulfate, filtered and evaporated to dryness. Further purification was achieved by silica gel column chromatography (the specific solvent mixture for each compound is given in the Supporting Information). The product was isolated and analyzed by ${ }^{1} \mathrm{H}$, ${ }^{13} \mathrm{C},{ }^{19} \mathrm{~F}$ NMR analysis, HRMS, melting point, UV/Vis and fluorescence emission.

Reaction of 5,15-bis[( $N$-4-prop-2-ynylamino)-2,3,5,6-tetrafluorophenyl]-10-(3-hydroxyphenyl)corrole (6) with 8-(N-4-prop-2-ynylamino)-2,3,5,6-tetrafluorophenyl)-4,4-difluoro-4-bora-3a,4a-diaza-sindacene (3b). Under argon atmosphere corrole 6 (21 mg, $24 \mu \mathrm{mol})$ was dissolved in dry DMSO $(3.0 \mathrm{~mL})$. After addition of BODIPY $\mathbf{3 b}(20 \mathrm{mg}, 50$ $\mu \mathrm{mol}, 2.1$ eq.), $\mathrm{CuSO}_{4} \cdot\left(\mathrm{H}_{2} \mathrm{O}\right)_{5}(12 \mathrm{mg}, 70 \mu \mathrm{mol}, 3.2$ eq.) and sodium ascorbate $(57 \mathrm{mg}, 0.28 \mathrm{mmol}, 12$ eq. $)$ the reaction mixture was stirred at $\mathrm{rt}$ for $3 \mathrm{~h}$. The reaction mixture was diluted with DCM, washed with water several times, dried with sodium sulfate, filtered and evaporated to dryness. The crude product was purified by column chromatography (silica gel, DCM $/ n$-hexane $=1: 1$ ) to obtain the product 7 as a red-brown solid (17 mg, 41\%). m.p. $185{ }^{\circ} \mathrm{C}$. ${ }^{1} \mathrm{H}$ NMR $\left(700 \mathrm{MHz}, \mathrm{CDCl}_{3}\right): \delta=2.32$ (dt, $J=13.0,6.4 \mathrm{~Hz}, 4 \mathrm{H}, \mathrm{CH}_{2}$ ), 3.55 (dd, $\left.J=13.0,6.5 \mathrm{~Hz}, 4 \mathrm{H}, \mathrm{CH}_{2}\right), 4.20(\mathrm{br}$ $\mathrm{s}, 2 \mathrm{H}, \mathrm{NH}), 4.58\left(\mathrm{t}, \mathrm{J}=6.6 \mathrm{~Hz}, 4 \mathrm{H}, \mathrm{CH}_{2}\right), 4.80\left(\mathrm{~d}, J=6.2 \mathrm{~Hz}, 4 \mathrm{H}, \mathrm{CH}_{2}\right)$, 4.85 (br s, $2 \mathrm{H}, \mathrm{NH}), 6.51$ (d, J = 3.6 Hz, $\left.4 \mathrm{H}, \mathrm{H}_{\text {pyrrole }}\right), 6.84$ (d, J = 3.7 Hz, $\left.4 \mathrm{H}, \mathrm{H}_{\text {pyrrole }}\right), 6.97-6.98(\mathrm{~m}, 1 \mathrm{H}, \mathrm{Ar}-\mathrm{H}), 6.99(\mathrm{~d}, \mathrm{~J}=8.2 \mathrm{~Hz}, 1 \mathrm{H}, \mathrm{Ar}-\mathrm{H})$, $7.11(\mathrm{~d}, J=8.2 \mathrm{~Hz}, 1 \mathrm{H}, \mathrm{Ar}-\mathrm{H}), 7.19(\mathrm{~d}, J=4.2 \mathrm{~Hz}, 2 \mathrm{H}, \beta-\mathrm{H}), 7.22-7.24$ $(\mathrm{m}, 2 \mathrm{H}, \beta-\mathrm{H}), 7.32(\mathrm{t}, J=7.8 \mathrm{~Hz}, 1 \mathrm{H}, \mathrm{Ar}-\mathrm{H}), 7.45-7.47$ (br s, $\left.2 \mathrm{H}, \mathrm{H}_{\text {Triazol }}\right)$, 7.60-7.61 (m, $2 \mathrm{H}, \beta-\mathrm{H}), 7.89-7.82$ (br s, $\left.6 \mathrm{H}, \mathrm{H}_{\text {pyrrole }}, \beta-\mathrm{H}\right)$ ppm. ${ }^{13} \mathrm{C} N M R$ $\left(176 \mathrm{MHz}, \mathrm{CDCl}_{3}\right)$ : The signal to noise ratio of the recorded ${ }^{13} \mathrm{C} \mathrm{NMR}$ spectrum did not allow a meaningful interpretation. ${ }^{19} \mathrm{~F}$ NMR $(376 \mathrm{MHz}$, $\left.\mathrm{CDCl}_{3}\right): \delta=-159.79\left(\mathrm{~m}_{\mathrm{c}}, J=18.4 \mathrm{~Hz}, 4 \mathrm{~F}, \mathrm{Ar}-\mathrm{F}_{\text {meta }}\right),-158.48\left(\mathrm{~m}_{\mathrm{c}}, J=\right.$ 16.0 Hz, $4 \mathrm{~F}$, Ar- $\left.\mathrm{F}_{\text {ortho }}\right),-144.70$ (q, J=28.4 Hz, $\left.4 \mathrm{~F}, \mathrm{BF}_{2}\right),-139.23\left(\mathrm{~m}_{\mathrm{c}}, J=\right.$

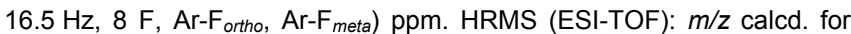
$\mathrm{C}_{79} \mathrm{H}_{47} \mathrm{~B}_{2} \mathrm{CuF}_{20} \mathrm{~N}_{18} \mathrm{NaO}^{+}[\mathrm{M}+\mathrm{Na}]^{+}$1751.3235; found 1751.3287. UV/Vis (DCM), $\lambda_{\max }\left[\log \varepsilon\left(\mathrm{L} \cdot \mathrm{mol}^{-1} \cdot \mathrm{cm}^{-1}\right)\right]: 412(5.00), 517(4.95) \mathrm{nm}$.

General procedure for the synthesis of substituted corroles. At rt the amino-substituted dipyrrane was dissolved in $\mathrm{MeOH}$ and the aldehyde was added. After addition of water and hydrochloric acid the mixture was stirred at $\mathrm{rt}$ for $1 \mathrm{~h}$. The reaction mixture was extracted with DCM several times, after that the organic layer was washed with water several times. The organic layer was dried with sodium sulfate, filtered and evaporated to dryness. The residue was dissolved in DCM, DDQ was added and the mixture refluxed for $1 \mathrm{~h}$. After filtration through silica gel the crude product was purified by silica gel column chromatography (the specific solvent mixture is given in the Supporting Information) and recrystallization ( $\mathrm{MeOH} /$ water). The product was isolated and analyzed 
by ${ }^{1} \mathrm{H},{ }^{13} \mathrm{C},{ }^{19} \mathrm{~F}$ NMR analysis, HRMS, melting point and UV/Vis spectroscopy.

General procedure for the synthesis of substituted $A_{2} B_{2}$-porpyhrins. Under argon atmosphere the amino-substituted dipyrrane was dissolved in DCM, aldehyde and a specific catalyst as indicated for each individual experiment in table 3 was added. The reaction mixture was shielded from ambient light and stirred at rt for $16 \mathrm{~h}$. DDQ was added, the mixture stirred for another $4 \mathrm{~h}$ and TEA was also added and stirred for another 15 min. After filtration through silica gel the solvent was evaporated to dryness. Further purification was achieved by silica gel column chromatography (specific solvent mixture is given in the Supporting Information) to obtain several successive fractions. The products were isolated and analyzed by ${ }^{1} \mathrm{H},{ }^{13} \mathrm{C},{ }^{19} \mathrm{~F}$ NMR analysis, HRMS, melting point and UV/Vis spectroscopy.

General procedure for the synthesis of multifunctionalized $A_{3} B$ - and trans- $A_{2} B_{2}$-porphyrins, starting from porphyrins carrying PFP. substituents. Under argon atmosphere the porphyrin was dissolved in dry THF or dry DMSO, the specific nucleophile was added (for alcohols as nucleophiles also the indicated amount of potassium hydroxide was added) and stirred for the time indicated for each individual experiment in table 4 and 5 , respectively. The mixture was diluted with DCM and washed with water several times. The organic layer was dried with sodium sulfate, filtered and evaporated to dryness. The crude product was purified by silica gel chromatography (the specific solvent mixture is given in the Supporting Information) and recrystallization. The product was isolated and analyzed by ${ }^{1} \mathrm{H},{ }^{13} \mathrm{C},{ }^{19} \mathrm{~F}$ NMR analysis, HRMS, melting point and UV/Vis spectroscopy.

General procedure for the synthesis of substituted hexaphyrins. Under argon atmosphere the substituted dipyrrane was dissolved in DCM PFP-aldehyde and $\mathrm{BF}_{3} \cdot \mathrm{OEt}_{2}$ were added and the mixture stirred at $0{ }^{\circ} \mathrm{C}$ for $2 \mathrm{~h}$. DDQ was added and the reaction mixture was stirred at $\mathrm{rt}$ for $16 \mathrm{~h}$. After neutralization with TEA the mixture was stirred for another 30 min and the reaction mixture was filtered (aluminum oxide) and the filtrate was evaporated to dryness. The residue was purified several times by silica gel column chromatography (the specific solvent mixture is given in the Supporting Information) to obtain two successive fractions. The first band refers to the $A_{2} B_{2}$-porphyrin and the second band refers to the hexaphyrin. The products were isolated and analyzed by ${ }^{1} \mathrm{H},{ }^{13} \mathrm{C},{ }^{19} \mathrm{~F}$ NMR analysis, HRMS, melting point and UV/Vis spectroscopy.

\section{X-ray crystallography}

Crystals were grown by dissolving the compounds in DCM and layering with $\mathrm{MeOH}$. Diffraction data for all compounds were collected on a Bruker APEX 2 DUO CCD diffractometer using graphite-monochromated $\operatorname{MoK}_{\alpha}(\lambda=0.71073 \AA)$ radiation. Crystals were mounted on a MiTeGen MicroMount and collected at 100(2) K using an Oxford Cryosystems Cobra low temperature device. Data was collected using omega and phi scans and were corrected for Lorentz and polarization effects using the APEX software suite. ${ }^{[53]}$ The structures were solved with Direct Methods and refined against $\left|\mathrm{F}^{2}\right|$ with the program SHELX using all data. ${ }^{[54]}$ Hydrogen atoms were fixed geometrically and allowed to ride on the parent carbon atoms, with aromatic $\mathrm{C}-\mathrm{H}=0.93 \AA$, and methyl $\mathrm{C}-\mathrm{H}=0.97$ $\AA$. The displacement parameters were set for aromatic $\mathrm{H}$ atoms at $\mathrm{U}_{\text {iso }}(\mathrm{H})=1.2 \mathrm{U}_{\text {eq }}(\mathrm{C})$, and methyl $\mathrm{H}$ atoms at $\mathrm{U}_{\text {iso }}(\mathrm{H})=1.5 \mathrm{U}_{\text {eq }}(\mathrm{C})$.

Crystal data and refinement of 3a: Crystal Data: $\mathrm{C}_{18} \mathrm{H}_{12} \mathrm{BF}_{6} \mathrm{~N}_{3}, M$ $=395.12$, monoclinic, space group $P 2_{1} / c, a=10.3054(7) \AA, \quad b=$ 13.6051(10) $\AA, c=12.1578(8) \AA, \alpha=90^{\circ}, \beta=104.183(2)^{\circ}, y=90^{\circ}, V=$
$1652.6(2) \AA^{3}, Z=4, T=99.99 \mathrm{~K}, \mu\left(M_{0 K}\right)=0.143 \mathrm{~mm}^{-1}, D_{\text {calc }}=1.588$ g.cm ${ }^{-3}, 38280$ reflections measured $\left(4.076^{\circ} \leq 2 \theta \leq 50.756^{\circ}\right), 3035$ unique $\left(R_{\text {int }}=0.0451, R_{\text {sigma }}=0.0220\right)$ which were used in all calculations. The final $R_{1}$ was $0.0390(I>2 \sigma(I))$ and $w R_{2}$ was 0.1044 (all data). Refinement: The structure was solved with disorder present in the allylamino moiety at N27 with both disordered parts being modelled with restraints (DFIX, SADI, ISOR) in a 51 and $49 \%$ occupancy.

Crystal data and refinement of 3d: Crystal Data: $\mathrm{C}_{17} \mathrm{H}_{12} \mathrm{BF}_{6} \mathrm{~N}_{3} \mathrm{O}, M$ $=399.11$, monoclinic, space group $C 2 / c, a=24.1941(14) \AA, b=7.0067(4)$ $\AA, c=19.3763(11) \AA, \alpha=90^{\circ}, \beta=97.4840(10)^{\circ}, y=90^{\circ}, V=3256.7(3)$ $\AA^{3}, Z=8, T=100.0 \mathrm{~K}, \mu\left(M_{0 K}\right)=0.150 \mathrm{~mm}^{-1}, D_{\text {calc }}=1.628 \mathrm{~g} . \mathrm{cm}^{-3}$, 44181 reflections measured $\left(3.396^{\circ} \leq 2 \theta \leq 60.29^{\circ}\right), 4802$ unique $\left(R_{\text {int }}=\right.$ $0.0174, R_{\text {sigma }}=0.0086$ ) which were used in all calculations. The final $R_{1}$ was $0.0326(\mathrm{I}>2 \sigma(\mathrm{I}))$ and $w R_{2}$ was 0.0935 (all data)

\section{In vitro testing}

Human epidermoid carcinoma cells A431 (DSMZ) and A253 (ATCC), squamous carcinoma cells CAL-27 (DSMZ), and colorectal adenocarcinoma cells HT29 (DSMZ) were grown in Dulbecco's modified eagle medium (DMEM) from cc-pro $\mathrm{GmbH}$ with $10 \%$ heat inactivated fetal calf serum (FCS) from cc-pro $\mathrm{GmbH}, 1 \%$ penicillin (10 $000 \mathrm{IU})$ and streptomycin (10 $000 \mu \mathrm{gmL}-1)$ from cc-pro $\mathrm{GmbH}$. A stock solution (2 $\mathrm{mM}$ ) of the photosensitizer (PS) was prepared at $4{ }^{\circ} \mathrm{C}$ in DMSO and kept in the dark. DMEM (without phenol red) with $10 \%$ FCS was used for further dilution to reach concentration 2 or $10 \mathrm{mM}$ of the PS, respectively. In micro plates $2 \times 10^{4}$ cells/well were seeded with fresh medium (DMEM without phenol red) containing $10 \%$ FCS with $0 \mu \mathrm{M}, 2 \mu \mathrm{M}$ or $10 \mu \mathrm{M}$ of the PS and incubated for $24 \mathrm{~h}$. After exchange of medium (to remove any PS not taken up by the cells) the photosensitization was performed at RT with a diode laser at $652 \mathrm{~nm}$ and $50 \mathrm{~J} / \mathrm{cm}^{2}$ (Ceralas PDT 652, CeramOptec $\mathrm{GmbH}$ ). The cell viability of the samples was measured with a Tecan Infinite 200 microplate reader at a wavelength of $490 \mathrm{~nm}$ and assessed using the XTT assay ${ }^{[55]}$ and the absorbance. A wavelength of 630 to $690 \mathrm{~nm}$ was used to measure the reference absorbance (for measuring the non-specific readings).

\section{Supporting Information}

See footnote on the first page of this article: Synthesis details and ${ }^{1} \mathrm{H},{ }^{13} \mathrm{C}$, and ${ }^{19} \mathrm{~F} \mathrm{NMR}$ and HRMS spectra for all new compounds. CCDC 1473017 (3a) and CCDC 1473016 (3d) contain the supplementary crystallographic data for this paper. These data can be obtained free of charge from The Cambridge Crystallographic Data Centre via www.ccdc.cam.ac.uk/data_request/cif.

\section{Acknowledgements}

Financial support by the German Bundesministerium für Bildung und Forschung (BMBF) (Project 'BioTraP for CCC', FKZ: 13N11386, biolitec research $\mathrm{GmbH}$ ) and Science Foundation Ireland (SFI IvP 13/IA/1894) is gratefully acknowledged.

Keywords: Porphyrinoids / Nucleophilic substitution / Fluorine / Amines / BODIPYs / PDT 
[1] a) T. Hasobe, in: Handbook of Porphyrin Science, World Scientific Publishing, Singapore, 2014, vol. 34, p. 147-194; b) L.-L. Li, E. W.-G Diau, Chem. Soc. Rev. 2013, 42, 291-304; c) G. Simonneaux, P. Le Maux, S. Chevance, H. Srour, in: Handbook of Porphyrin Science, World Scientific Publishing, Singapore. 2012, vol. 21, p. 377-410; d) E. E. Benson, C. P. Kubiak, A. J. Sathrum, J. M. Smieja, Chem. Soc. Rev. 2009, 38, 89-99; e) M. O. Senge, A. Wiehe, C. Ryppa, in: Advances in Photosynthesis and Respiration, 2006, vol. 25, p. 27-37; f) A. A. Ryan, M. O. Senge, Photochem. Photobiol. Sci. 2015, 14, 638-660.

[2] J. S. Lindsey, in: The Porphyrin Handbook. Academic Press; Kadish, K. M., Smith, K.M., Guilard, R. (Eds.); Academic Press: San Diego, 2000 Vol. 1, pp 45-118.

[3] a) D. Wang, J. T. Groves, Proc. Natl. Acad. Sci. USA 2013, 110, 15579-15584; b) C.-M. Che, V. K.-Y. Lo, C.-Y. Zhou, J.-S. Huang Chem. Soc. Rev. 2011, 40, 1950-1975; c) I. Aviv, Z. Gross, Chem. Commun. 2007, 1987-1999; d) G. B. Shul'pin, J. Mol. Catal. A 2002, 189, 39-66.

[4] a) M. Urbani, M. Grätzel, M. K. Nazeeruddin, T. Torres, Chem. Rev. 2014, 114, 12330-12396; b) Y.-C. Chang, C.-L. Wang, T.-Y. Pan, S.-H. Hong, C.-M. Lan, H.-H. Kuo, C.-F. Lo, H.-Y. Hsu, C.-Y. Lin, E. W.-G. Diau, Chem. Commun. 2011, 47, 8910-8912.

[5] a) C. M. Drain, A. Varotto, I. Radivojevic, Chem. Rev. 2009, 109, 1630 1658; b) M. O. Senge, M. Fazekas, E. G. A. Notaras, W. J. Blau, M. Zawadzka, O. B. Locos, E. M. Ni Mhuircheartaigh, Adv. Mater. 2007, 19 2737-2774; c) M. Zawadzka, J. Wang, W. J. Blau, M. O. Senge Photochem. Photobiol. Sci. 2013, 12, 996-1007.

[6] a) L. B. Josefsen, R. W. Boyle, Theranostics 2012, 2, 916-966; b) M. Ethirajan, Y. Chen, P. Joshi, R. K. Pandey, Chem. Soc. Rev. 2011, 40, 340-362; c) L. B. Josefsen, R. W. Boyle, Metal-Based Drugs 2007, ID 276109, $24 \mathrm{pp}$.

[7] a) B. Chauvin, B. I. Iorga, P. Chaminade, J.-L. Paul, P. Maillard, P. Prognon, A. Kasselouri, Eur. J. Pharm. Biopharm. 2013, 83, 244-252 b) E. S. Nyman, P. H. Hynnien, J. Photochem. Photobiol. B 2004, 73 1-28; c) A. Wiehe, E. J. Simonenko, M. O. Senge, B. Röder, J. Porphyrins Phthalocyanines 2001, 5, 758-761.

[8] a) J. S. Lindsey, Acc. Chem. Res. 2010, 43, 300-311; b) M. O. Senge, Y. M. Shaker, M. Pintea, C. Ryppa, S. S. Hatscher, A. Ryan, Y Sergeeva, Eur. J. Org. Chem. 2010, 237-258; c) J. S. Lindsey, I. C. Schreimann, H. C. Hsu, P. C. Kearney, A. M. Marguerettaz, J. Org. Chem. 1987, 52, 827-836

[9] a) N. V. S. D. K. Bhupathiraju, W. Rizvi, J. D. Batteas, C. M. Drain, Org. Biomol. Chem. 2016, 14, 389-408; b) T. Goslinski, J. Piskorz, J. Photochem. Photobiol. C 2011, 12, 304-321; c) J. I. T. Costa, A. C. Tomé, M. G. M. S. Neves, J. A. S. Cavaleiro, J. Porphyrins Phthalocyanines 2011, 15, 1117-1133; d) M. A. Hyland, M. D. Morton, C. Brückner, J. Org. Chem. 2012, 77, 3038-3048; e) J. Kvíčala, M. Beneš, O. Paleta, V. Král, J. Fluor. Chem. 2010, 131, 1327-1337; f) A Pažitný, T. Solčán, D. Végh, J. Fluor. Chem. 2009, 130, 267-294; g) M. Suzuki, S. Shimizu, J.-Y. Shin, A. Osuka, Tetrahedron Lett. 2003, 44, 4597-4601.

[10] a) J. Králová, Z. Kejík, T. Bríza, P. Poucková, A. Král, P. Martásek, V. Král, J. Med. Chem. 2010, 53, 128-138; b) P. Battioni, O. Brigaud, H. Desvaux, D. Mansuy, T. G. Traylor, Tetrahedron Lett. 1991, 32, 28932896.

[11] T. Hori, A. Osuka, Eur. J. Org. Chem. 2010, 2379-2386.

[12] a) H. R. A. Golf, H.-U. Reissig, A. Wiehe, Eur. J. Org. Chem 2015 1548-1568; b) J. F. B. Barata, A. Zamarrón, M. G. P. M. S. Neves, M. A. F. Faustino, A. C. Tomé, J. A. S. Cavaleiro, B. Röder, Á Juarranz, F Sanz-Rodríguez, Eur. J. Med. Chem. 2015, 92, 135-144; c) H. R. A. Golf, H.-U. Reissig, A. Wiehe, J. Org. Chem. 2015, 80, 5133-5143; d) T. A. F. Cardote, J. F. B. Barata, M. A. F. Faustino, A. Preuß, M. G. P. M. S. Neves, J. A. S. Cavaleiro, C. I. V. Ramos, M. G. O. SantanaMarques, B. Röder, Tetrahedron Lett. 2012, 53, 6388-6393.

[13] a) M. Schmidlehner, F. Faschinger, L. M. Reith, M. Ertl, W. Schoefberger, Appl. Organomet. Chem. 2013, 27, 395-405; b) J.
Tüxen, S. Eibenberger, S. Gerlich, M. Arndt, M. Mayor, Eur. J. Org. Chem. 2011, 4823-4833; c) L. F. Pedrosa, M. C. de Souza, M. A. F Faustino, M. G. P. M. S. Neves, A. M. S. Silva, A. C. Tomé, V. F. Ferreira, J. A. S. Cavaleiro, Aust. J. Chem. 2011, 64, 939-944; d) J. Králová, T. Bríza, I. Moserová, B. Dolenský, P. Vasek, P. Poucková, Z. Kejík, R. Kaplánek, P. Martásek, M. Dvorák, V. Král, J. Med. Chem. 2008, 51, 5964-5973; e) D. Samaroo, C. E. Soll, L. J. Todaro, C. M. Drain, Org. Lett. 2006, 8, 4985-4988; f) K. M. Kadish, C. AraulloMcAdams, B. C. Han, M. M. Franzen, J. Am. Chem. Soc. 1990, 112, 8364-8368.

[14] a) A. Aggarwal, S. Thompson, S. Singh, B. Newton, A. Moore, R. Gao, X. Gu, S. Mukherjee, C. M. Drain, Photochem. Photobiol. 2014, 90 419-430; b) R. E. Mewis, H. Savoie, S. J. Archibald, R. W. Boyle, Photodiagn. Photodyn. Ther. 2009, 6, 200-206; c) K. J. Elgie, M. Scobie, R. W. Boyle, Tetrahedron Lett. 2000, 41, 2753-2757; d) S. J. Shaw, K. J. Elgie, C. Edwards, R. W. Boyle, Tetrahedron Lett. 1999, 40, 1595-1596.

[15] a) D. T. Gryko, D. Wyrostek, A. Nowak-Król, K. Abramczyk, M. K Rogacki, Synthesis 2008, 4028-4032; b) J. F. W. Keana, S. X. Cai, J. Org. Chem. 1990, 55, 3640-3647.

[16] H. R. A. Golf, H.-U. Reissig, A. Wiehe, Org. Lett. 2015, 17, 982-985.

[17] a) N. A. M. Pereira, T. M. V. D. Pinho e Melo, Org. Prep. Proc. Int. 2014, 46, 183-213; b) D. T. Gryko, D. Gryko, C.-H. Lee, Chem. Soc. Rev. 2012, 41, 3780-3789; c) S. M. M. Lopes, A. Lemos, T. M. V. D. Pinho e Melo, Eur. J. Org. Chem. 2014, 7039-7048; d) S. C. C. Nunes, S. M. M. Lopes, C. S. B. Gomes, A. Lemos, , A. A. C. C. Pais, T. M. V. D. Pinho e Melo, J. Org. Chem. 2014, 79, 10456-10465; e) B. Koszarna, D. T. Gryko, J. Org. Chem. 2006, 71, 3707-3717; f) B. J. Littler, Y. Ciringh, J. S. Lindsey, J. Org. Chem. 1999, 64, 2864-2872; g) C.-H. Lee, J. S. Lindsey, Tetrahedron 1994, 50, 11427-11440.

[18] a) M. O. Senge, Chem. Commun. 2011, 47, 1943-1960; b) S. Saito, A Osuka, Angew. Chem. Int. Ed. 2011, 50, 4342-4373; Angew. Chem. 2011, 123, 4432-4464; c) M. Suzuki, A. Osuka, Org. Lett. 2003, 5 3943-3946; d) D. T. Gryko, B. Koszarna, Org. Biomol. Chem. 2003, 1, 350-357; e) M. H. Beyzavi, D. Lentz, H.-U. Reissig, A. Wiehe, Chem. Eur. J. 2013, 19, 6203-6208; f) P. A. Gale, P. Anzenbacher, Jr., J. L. Sessler, Coord. Chem. Rev. 2001, 222, 57-102.

[19] a) K. C. G. Sreedevi, A. P. Thomas, P. S. Salini, S. Ramakrishnan, K. S. Anju, M. G. D. Holaday, M. L. P. Reddy, C. H. Suresh, A. Srinivasan, Tetrahedron Lett. 2011, 52, 5995-5999; b) T. Tsuchimoto, K. Hatanaka, E. Shirakawa, Y. Kawakami, Chem. Commun. 2003, 2454-2455.

[20] G. R. Geier III, B. J. Littler, J. S. Lindsey, J. Chem. Soc. Perkin Trans. 2, 2001, 701-711.

[21] B. J. Littler, M. A. Miller, C.-H. Hung, R. W. Wagner, D. F. O'Shea, P. D. Boyle, J. S. Lindsey, J. Org. Chem. 1999, 64, 1391-1396.

[22] For the synthesis of the starting material 3-azidopropylamine, see: $Y$ Yu, Y. Li, S. Chen, T. Liu, Z. Qin, H. Liu, Y. Li, Eur. J. Org. Chem. 2012, 4287-4292.

[23] a) A. Kamkaew, S. H. Lim, H. B. Lee, L. V. Kiew, L. Y. Chung, K Burgess, Chem. Soc. Rev. 2013, 42, 77-88; b) S. G. Awuah, Y. You, RSC Adv. 2012, 2, 11169-11183; c) A. M. Durantini, L. E. Greene, R. Lincoln, S. R. Martínez, G. Cosa, J. Am. Chem. Soc. 2016, 138, 1215-1225.

[24] a) R. Ziessel, G. Ulrich, A. Harriman, New J. Chem. 2007, 31, 496-501; b) Y. Ni, J. Wu, Org. Biomol. Chem. 2014, 12, 3774-3791.

[25] a) N. Boens, V. Leen, W. Dehaen, Chem. Soc. Rev. 2012, 41, 11301172; b) A. Loudet, K. Burgess, Chem. Rev. 2007, 107, 4891-4932; c) A. Treibs, F. H. Kreuzer, Justus Liebigs Ann. Chem. 1968, 718, 208223.

[26] G. Vives, C. Giansante, R. Bofinger, G. Raffy, A. D. Guerzo, B. Kauffmann, P. Batat, G. Jonusauskas, N. D. McClenaghan, Chem. Commun. 2011, 47, 10425-10427.

[27] V. Leen, V. Z. Gonzalvo, W. M. Deborggraeve, N. Boens, W. Dehaen, Chem. Commun. 2010, 46, 4908-4910. 
[28] a) H. R. A. Golf, A. M. Oltmanns, D. H. Trieu, H.-U Reissig, A. Wiehe, Eur. J. Org. Chem. 2015, 4224-4237; b) B. Schulze, U. S. Schubert, Chem. Soc. Rev. 2014, 43, 2522-2571; c) R. Berg, B. F. Straub, Beilstein J. Org. Chem. 2013, 9, 2715-2750.

[29] a) H. L. Buckley, L. K. Rubin, M. Chromiński, B. J. McNicholas, K. H. Y. Tsen, D. T. Gryko, J. Arnold, Inorg. Chem. 2014, 53, 7941-7950; b) T. H. Ngo, W. v. Rossom, W. Dehaen, W. Maes, Org. Biomol. Chem. 2009, 7, 439-443; c) C. Brückner, R. P. Brinas, J. A. K. Bauer, Inorg Chem. 2003, 42, 4495-4497.

[30] a) B. Basumatary, A. R. Sekhar, R. V. Ramana Reddy, J. Sankar, Inorg Chem. 2015, 54, 4257-4267; b) W. Chen, J. Zhang, J. Mack, G. Kubheka, T. Nyokong, Z. Shen, RSC Adv. 2015, 5, 50962-50967; c) B Brizet, N. Desbois, A. Bonnot, A. Langlois, A. Dubois, J.-M. Barbe, C. P. Gros, C. Goze, F. Denat, P. D. Harvey, Inorg. Chem. 2014, 53, 3392-3403; d) E. Ganapathi, S. Madhu, M. Ravikanth, Tetrahedron 2014, 70, 664-671; e) T. K. Khan, M. Bröring, S. Mathur, M. Ravikanth, Coord. Chem. Rev. 2013, 257, 2348-2387; f) A. Eggenspiller, A. Takai, M. E. El-Khouly, K. Ohkubo, C. P. Gros, C. Bernhard, C. Goze, F. Denat, J.-M. Barbe, S. Fukuzumi, J. Phys. Chem. A 2012, 116, 3889 3898.

[31] V. I. Vaz Serra, S. M.G. Pires, C. M. A. Alonso, M. G. P. M. S. Neves, A. C. Tomé, J. A. S. Cavaleiro, Top. Heterocycl. Chem. 2014, 33, 35-78.

[32] S.-J. Hong, M.-H. Lee, C.-H. Lee, Bull. Korean Chem. Soc. 2004, 25, 1545-1551.

[33] C.-H. Lee, F. Li, K. Iwamoto, J. Dadok, A. A. Bothner-By, J. S. Lindsey, Tetrahedron 1995, 51, 11645-11672.

[34] G. R. Geier III, Y. Ciringh, F. Li, D. M. Haynes, J. S. Lindsey, Org. Lett. 2000, 2, 1745-1748.

[35] G. R. Geier III, J. S. Lindsey, Tetrahedron 2004, 60, 11435-11444.

[36]G. R. Geier III, B. J. Littler, J. S. Lindsey, J. Chem. Soc. Perkin Trans. 2 2001, 701-711.

[37] S. P. Foxon, J. R. Lindsay Smith, P. O'Brien, G. J. Reginato, J. Chem. Soc, Perkin Trans. 2 2001, 1145-1153.

[38] F. R. Kooriyaden, S. Sujatha, B. Varghese, C. J. Arunkumar, J. Fluor Chem. 2015, 170, 10-16.

[39] For rearrangement of propargylic ethers into alkoxyallenes, see: S. Hoff, L. Brandsma, J. F. Arens, Rec. Trav. Chim. Pays-Bas 1968, 87, 916924.

[40] a) R. Misra, T. K. Chandrashekar, Acc. Chem. Res. 2008, 41, 265-279; b) J. L. Sessler, D. Seidel, Angew. Chem. Int. Ed. 2003, 42, 5134 5175; Angew. Chem. 2003, 115, 5292-5333; c) S. Shimizu, J.-Y. Shin, H. Furuta, R. Ismael, A. Osuka, Angew. Chem. Int. Ed. 2003, 42, 7882; Angew. Chem. 2003, 115, 82-86.

[41] M. G. P. M. S. Neves, R. M. Martins, A. C. Tome, A. J. D. Silvestre, A. M. S. Silva, V. Felix, J. A. S. Cavaleiro, M. G. B. Drew, Chem. Commun. 1999, 385-386.

[42] M. Suzuki, A. Osuka, Chem. Eur. J. 2007, 13, 196-202.

[43] J.-Y. Shin, T. Tanaka, A. Osuka, Q. Miao, D. Dolphin, Chem. Eur. J. 2009, 15, 12955-12959.

[44] J.-Y. Shin, H. Furuta, K. Yoza, S. Igarashi, A. Osuka, J. Am. Chem. Soc. 2001, 123, 7190-7191

[45] F. Figueira, A. S. F. Farinha, P. V. Muteto, M. D. Poleto, H. Verli, M. T. S. R. Gomes, A. C. Tomé, J. A. S. Cavaleiro, J. P. C. Tomé, Chem. Commun. 2016, 52, 2181-2184.

[46] T. Yoneda, T. Kim, T. Soya, S. Neya, J. Oh, D. Kim, A. Osuka, Chem. Eur. J. 2016, 22, 4413-4417.

[47] L. Simkhovich, I. Goldberg, Z. Gross, Org. Lett. 2003, 5, 1241-1244. A sample of meso-hexakis(pentafluorophenyl)-[26]hexaphyrin was also synthesized for comparison and the ${ }^{1} \mathrm{H}$ - and ${ }^{19} \mathrm{~F}-\mathrm{NMR}$ spectra were measured.

[48] N. Hewage, B. Yang, A. G. Agrios, C. Brückner, Dyes Pigm. 2015, 121, 159-169.

[49] a) M. O. Senge, J. C. Brandt, Photochem. Photobiol. 2011, 87, 1240 1296; b) R. R. Allison, C. H. Sibata, Photodiagn. Photodyn. Ther. 2010
7, 61-75; c) R. R. Allison, R. E. Cuenca, G. H. Downie, P. Camnitze, B. Brodish, C. H. Sibata, Photodiagn. Photodyn. Ther. 2005, 2, 205-222.

[50] a) K. Moghissi, K. Dixon, S. Gibbins, Surg. J. 2015, 1, e1-e15, DOI: 10.1055/s-0035-1565246; b) R. A. Weersink, A. Bogaards, M. Gertner, S. R. H. Davidson, K. Zhang, G. Netchev, J. Trachtenberg, B. C. Wilson, J. Photochem. Photobiol. B 2005, 79, 211-222; c) Z. Huang, Technol Cancer Res Treat. 2005, 4, 283-293.

[51] S. Hirohara, K. Sharyo,Y. Kawasaki, M. Totan, A. Tomotsuka, R. Funasako, N. Yasui, Y. Hasegawa, J. Yausa, T. Nakashima, T. Kawai, C. Oka, M. Kawaichi, M. Obata, M. Tanihara, Bull. Chem. Soc. Jpn. 2013, 86, 1295-1308.

[52] I. Laville, T. Figueiredo, B. Loock, S. Pigaglio, Ph. Maillard, D. S Grierson, D. Carrez, A. Croisy, J. Blais, Bioorg. Med. Chem. 2003, 11, 1643-1652.

[53] Bruker. (2014). SAINT, APEX2 and SADABS. Bruker AXS Inc., Madison, Wisconsin, USA.

[54] a) G. M. Sheldrick, Acta Cryst. 2015, A71, 3-8; b) G. M. Sheldrick, Acta Cryst. 2015, C71, 3-8; c) O. V. Dolomanov, L. J. Bourhis, R. J. Gildea, J. A. K. Howard, H. Puschmann, J. Appl. Cryst. 2009, 42, 339-341.

[55] M. V. Berridge, P. M. Herst, A. S. Tan, Biotechnol. Ann. Rev. 2005, 11, $127-152$. 


\section{Entry for the Table of Contents}

\section{FULL PAPER}

Alternatively to an amino-substitution on the final porphyrinoid or BODIPY the precursor PFP-dipyrrane can be modified with different amines (or alcohols). These dipyrranes were transformed to specifically substituted corroles, porphyrins, hexaphyrins and BODIPYs. Selected porphyrins were tested for their PDT activity.
(Key Topic) Porphyrinoids

Claudia S. Gutsche, Marlene Ortwerth,

Susanna Gräfe, Keith J. Flanagan

Mathias O. Senge, Hans-Ulrich Reissig,

Nora Kulak, Arno Wiehe*

Page No. - Page No.

Nucleophilic Aromatic Substitution

on Pentafluorophenyl-substituted

Dipyrranes and Tetrapyrroles as a

Route to Multifunctionalized

Chromophores for a Potential

Application in Photodynamic Therapy 